\title{
Weinreb Amides as Directing Groups for Transition Metal-Catalyzed C-H Functionalizations
}

\author{
Jagadeesh Kalepu and Lukasz T. Pilarski *(1) \\ Department of Chemistry-BMC, Uppsala University, BOX 576, 75-123 Uppsala, Sweden; \\ jagadeesh.kalepu@kemi.uu.se \\ * Correspondence: lukasz.pilarski@kemi.uu.se \\ Academic Editor: Michal Szostak \\ Received: 28 January 2019; Accepted: 15 February 2019; Published: 26 February 2019
}

\begin{abstract}
Weinreb amides are a privileged, multi-functional group with well-established utility in classical synthesis. Recently, several studies have demonstrated the use of Weinreb amides as interesting substrates in transition metal-catalyzed C-H functionalization reactions. Herein, we review this part of the literature, including the metal catalysts, transformations explored so far and specific insights from mechanistic studies.
\end{abstract}

Keywords: C-H functionalization; directing groups; amides; transition metals; catalysis

\section{Introduction}

The pursuit of efficient methods for the direct, catalytic substitution of otherwise inert C-H bonds in organic molecules has become a major area of research focus in recent years [1]. Tremendous advances have been made in the development of previously impossible transformations [2-5], mechanistic understanding [6-9], milder and safer protocols [10], and selectivity [11-14]. The ubiquity of $\mathrm{C}-\mathrm{H}$ bonds in organic molecules makes their regioselective activation and substitution particularly attractive, but also challenging. To this end, the use of directing groups-parts of an organic substrate that can coordinate to and position a metal center over the desired C-H bond-has met with enormous success [15]. The use of ortho-directing groups especially has provided the basis of many new homogeneous catalytic C-H functionalization reactions [16]. Directing groups able to deliver meta $[17,18]$ and para [19] selectivity in C-H functionalization catalysis have also been described, although the generality of that approach is still some way off in the future.

Ideally, directing groups should not require separate and/or laborious installation/removal or otherwise be inutile in later steps of a synthesis. It is preferable that they should either be part of the desired target compound or that they could be converted to another useful group once their role during the C-H functionalization step is over. A plethora of strategies to realize the latter objective has been pursued. The invention of various removable or modifiable [20-22], traceless [23], or otherwise transient [24-29] directing groups has formed a sizeable category in and of itself within the field of C-H functionalization catalysis.

Amides are an incomparably important class of compounds. The development of methods for their selective synthesis and derivatization is, therefore, a key pursuit in synthetic methodology. That the amide group can serve as a ligand for transition metals enables various new approaches to this via catalytic C-H functionalization [30]. Most commonly, the amide group has been called upon to direct the catalytic substitution of neighboring Ar-H bonds but, as discussed below, they also enable $\mathrm{C}\left(\mathrm{sp}^{3}\right)-\mathrm{H}$ bond manipulation.

$N$-methoxy- $N$-methyl amides (1, Figure 1), or Weinreb amides [31], are a valuable branch of the amide family. They provide the 'textbook' route to mono-addition products (especially ketones 
and aldehydes) via nucleophilic attack on the carbonyl group. Such attacks give rise to stable five-membered tetrahedral cyclic intermediates (2) to which a second addition ("over-addition") is precluded. Weinreb amides may be prepared with ease from carboxylic acids or their chlorides, esters, aldehydes or ketones [32].

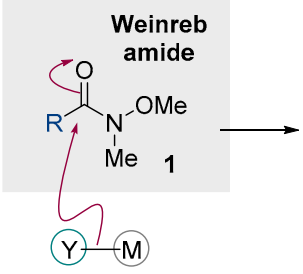

nucleophile

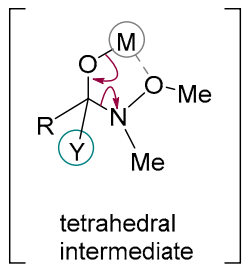

2

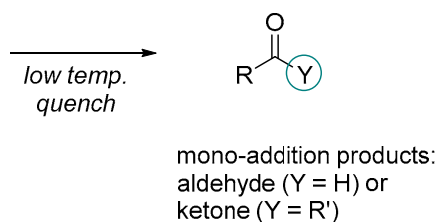

ketone $\left(Y=R^{\prime}\right)$

Figure 1. The 'textbook' application of Weinreb amides: generation of mono-addition products resulting from nucleophilic attack on their carbonyl groups.

That Weinreb amides can also steer the regioselectivity of transition metal-catalyzed C-H functionalizations (Figure 2) qualifies them as noteworthy multi-functional directing groups. Remarkably, and despite the various synthetic advantages of this (for example that it can obviate the need for lithiation strategies and make available previously impossible reactions), Weinreb amides have only recently attracted attention as substrates for $\mathrm{C}-\mathrm{H}$ functionalization. In part, this is due to the amide oxygen's weaker coordination ability to most transition metal centers. The latter has presented a challenge to the development of their use in $\mathrm{C}-\mathrm{H}$ functionalization reactions, although many carbonyl-directed reactions are now known [33].

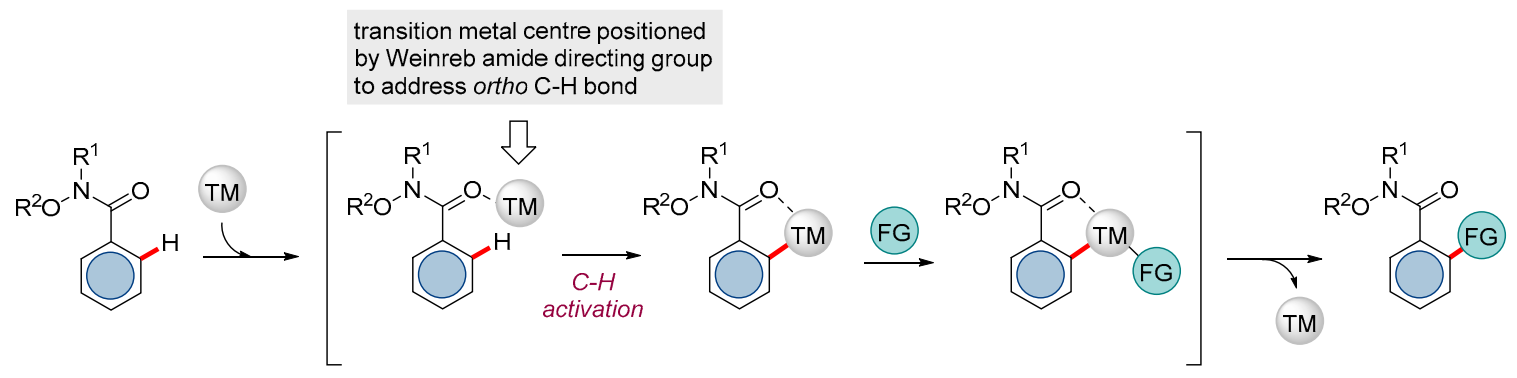

Figure 2. A generic representation of a Weinreb amide-directed catalytic C-H functionalization

(TM = transition metal).

This review describes progress in the use of Weinreb amides as directing groups in catalytic C-H functionalization. A variety of reactions falls under this category. We have chosen to group these according to the transition metal center responsible for the $\mathrm{C}-\mathrm{H}$ functionalization catalysis, rather than the overall transformation, in order to maximize the ease of comparison between researchers working in similar areas, and to track the different rates at which progress has occurred and insights in to the underlying mechanisms. Overwhelmingly, the focus of the studies reviewed herein falls on the utility of Weinreb amides as directing groups for the $\mathrm{C}-\mathrm{H}$ functionalization step. Therefore, whilst several publications describe subsequent manipulation of the Weinreb amide group, this is usually to illustrate the possibility, rather than a key development. We have opted therefore not to include many examples of the latter; we take the possibility of a posteriori conversion of Weinreb amides using conventional approaches (e.g., to ketones or aldehydes), for the most part, to be a safe assumption.

\section{Ru-catalyzed Reactions}

The versatility of $\mathrm{Ru}$, as well as its considerably lower price compared to other 2nd and 3rd-row transition metals, make it an appealing candidate around which to develop economical $\mathrm{C}-\mathrm{H}$ functionalization methodology [34,35]. Moreover, considerable advances have been made in 
Ru-catalyzed C-H functionalization directed by weakly coordinating groups, including amides [33]. In 2013, Ackermann and co-workers described the Weinreb amide-directed C-H ortho-oxygenation of arenes 3 using a $\mathrm{Ru}(\mathrm{II})$-based system [36]. [ $\mathrm{RuCl}_{2}$ (p-cymene) $]_{2}$ served as the catalyst precursor and $\mathrm{PhI}(\mathrm{OAc})_{2}$ as the most effective oxidant. Representative results from the study are shown in Scheme $1 \mathrm{a}$.

A. Representative scope of Ru(II)-catalyzed C-H ortho-oxygenation of Weinreb amides:

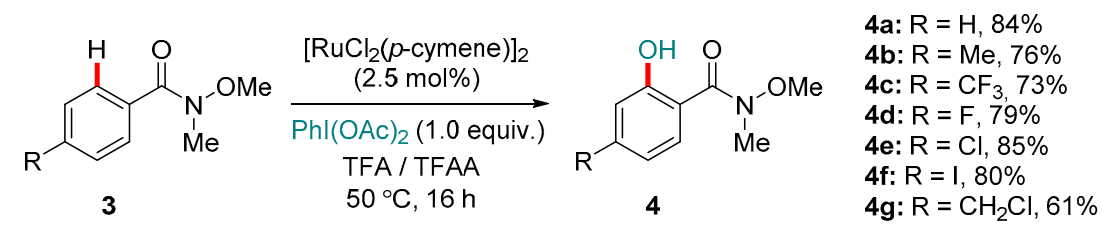

B. Reduction of the Weinreb amide directing group to the corresponding aldehyde:

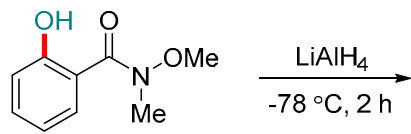

$4 a$

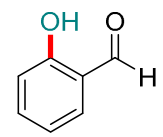

5: $82 \%$

Scheme 1. $\mathrm{Ru}(\mathrm{II})$-catalyzed $\mathrm{C}-\mathrm{H}$ oxidation of arenes directed by a Weinreb amide group. (a) Representative scope of the reaction with respect to arene substituents; (b) Reduction of the Weinreb amide to reveal aldehyde functionality.

The reaction showed a high selectivity for mono-oxygenated products 4 , a preference for electron-rich substrates in competition experiments, and a kinetic isotope effect (KIE) of $k_{\mathrm{H}} / k_{\mathrm{D}}=3.0$ [6]. The authors proposed that an irreversible $\mathrm{C}-\mathrm{H}$ activation event was a key step en route to the products. It is notable that the $N$-alkyl substituent could also be varied substantially without any loss of reaction efficiency. The Weinreb amide group could be reduced in high yield (4a to 5 ) to reveal the corresponding aldehyde (Scheme 1b). A single Weinreb amide substrate was also shown to work as part of a study by Jeganmohan and co-workers on the ortho-directed C-H benzoyloxylation of various amides. The reaction system closely resembled that reported above by Ackermann, except for the use of $\left(\mathrm{NH}_{4}\right) \mathrm{S}_{2} \mathrm{O}_{8}$ as the terminal oxidant, higher temperatures and use of 1,2-dichloroethane as solvent [37].

Subsequently, Das and Kapur produced a report demonstrating the Ru-catalyzed olefination of various amides, including Weinreb amide-decorated arenes [38]. The protocol closely resembles the Pd-catalyzed oxidative Heck reaction [39] (also known as the Fujiwara-Moritani reaction) and other related Ru-catalyzed C-H alkenylations [34]. However, for the majority of their entries (selected examples are shown in Scheme 2a), the authors observed cleavage of the Weinreb amide $\mathrm{N}-\mathrm{O}$ bond; $\mathrm{N}$-methyl amides were obtained as the main products. It is instructive to consider the proposed mechanism, an adapted version of which is shown in Scheme 2b. Presumably, the $\mathrm{N}-\mathrm{O}$ bond serves as an oxidant with $\mathrm{Cu}(\mathrm{OAc})_{2} \cdot \mathrm{H}_{2} \mathrm{O}$ as the carboxylate source to facilitate repeated C-H functionalization [40] The use of similar "internal oxidant" strategies in C-H functionalization, including using $\mathrm{N}$-methoxy amides, has been recently reviewed by Cui and co-workers [41]. Exceptions wherein the $\mathrm{N}-\mathrm{O}$ bond was preserved presumably resulted from $\mathrm{Cu}$ (II) (or $\mathrm{Cu}$ (III) species arising via disproportionation) outcompeting $\mathrm{N}-\mathrm{O}$ as an internal oxidant. The importance of such examples is under-appreciated, in our view. That an exogenous oxidant may divert reactivity away from damaging a group under otherwise identical conditions is a key aspect of modulating functional group tolerance; a factor that will govern the extent to which $\mathrm{C}-\mathrm{H}$ activation-and other catalytic methods-gain acceptance as generalizable routes to construct molecular complexity.

Das and Kapur reported that five-membered cyclic amides of the type $7(n=0)$ typically underwent $\mathrm{N}-\mathrm{O}$ bond cleavage, affording ring-opened products. To prevent this, and thereby retain the Weinreb amide functionality, they subsequently sought to show that $\mathrm{N}-\mathrm{O}$ bond cleavage could be prevented through judicious substrate design [42]. Increasing the Weinreb amide size to six- and 
seven-membered rings $(7, n=1$ or 2 , respectively) rendered the $\mathrm{N}-\mathrm{O}$ bond cleavage energetically unfavorable. Under otherwise unchanged conditions, the oxidative C-H olefination afforded products 8 (Scheme 3), restoring $\mathrm{Cu}(\mathrm{II})$ to its role as the terminal oxidant. Further manipulation of the cyclic Weinreb amide moieties in $\mathbf{8}$, for example in their conversion to the corresponding aldehyde or ketones, was demonstrated to proceed in high yield.
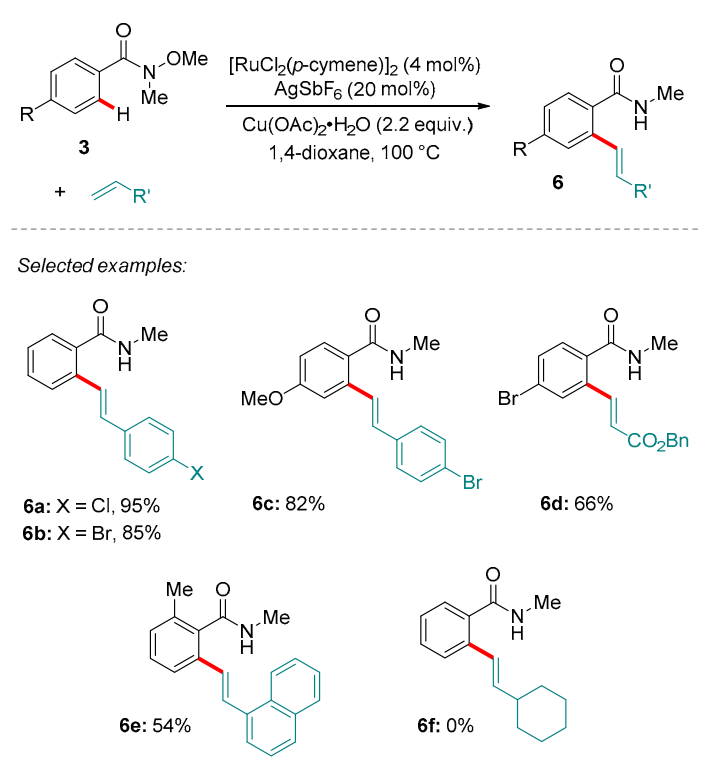

(a)

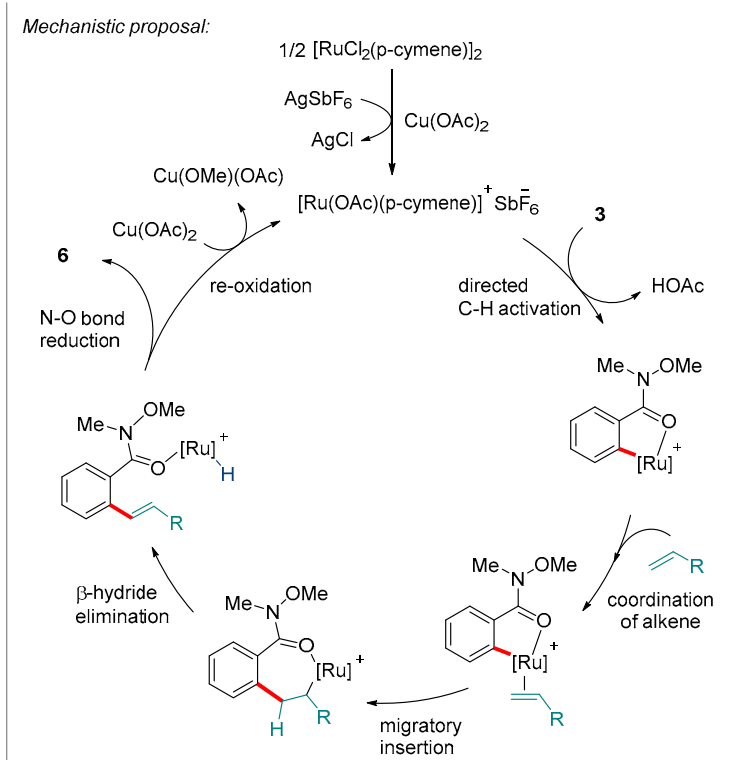

(b)

Scheme 2. $\mathrm{Ru}(\mathrm{II})$-catalyzed oxidative $\mathrm{C}-\mathrm{H}$ ortho-alkenylation of Weinreb amides; selected products and proposed mechanism.

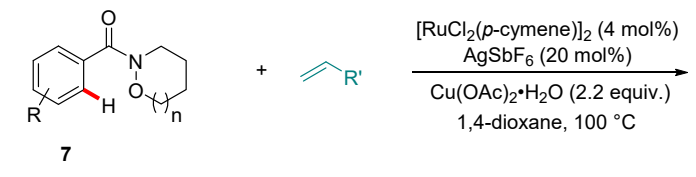

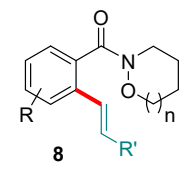

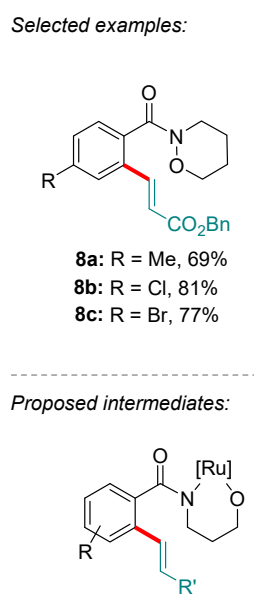

9a

6-membered ruthenacycle (accessible)

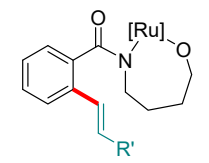

$9 b$

7-membered ruthenacycle (disfavored)

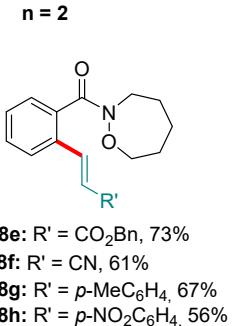

8g: $\mathrm{R}^{\prime}=p-\mathrm{NeC}_{6} \mathrm{H}_{4}, 67 \%$

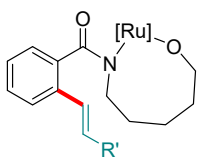

9c

8-membered ruthenacycle (disfavored)

Scheme 3. Ru-catalyzed C-H olefination using directed by cyclic Weinreb amides without N-O bond cleavage. Putative intermediates $\mathbf{9 a}-\mathbf{c}$ are suggested to arise from the insertion of $\mathrm{Ru}$ into the substrate $\mathrm{N}-\mathrm{O}$ bond. 
An explanation for the greater relative stability of the 6- and 7-membered cyclic Weinreb amide groups in this protocol was proposed: In the course of the reaction, oxidative addition of the Ru center to the $\mathrm{N}-\mathrm{O}$ bond would furnish intermediates of type 9. Of these, only the formation of 9a would be favorable; the 7- and 8-membered ruthenacycles (9b and $\mathbf{9 c}$, respectively) are presumably too high in energy to be accessed.

\section{Co-catalyzed Reactions}

The expense and eventual scarcity of second- (4d) and third-row (5d) transition metals has, in recent years, motivated a shift towards exploring the potential of their more abundant first-row (3d) cousins for catalytic C-H functionalization [43]. Cobalt stands out in this context as a comparatively cheap, abundant option that comes with a proven track record in broad areas of homogenous catalysis, including several industrially important reactions [44-46].

In 2013, Yoshino and Matsunaga disclosed the first C-H ortho-directed functionalization catalyzed by $\mathrm{Cp}^{*} \mathrm{Co}(\mathrm{III})$ species $[47,48]$. In a subsequent study on the Co-catalyzed C-H allylation of aryl purines and benzamides using allylic alcohol, they demonstrated the new reaction also on Weinreb amide 3a [49]. Here, the bench-stable complex $\mathrm{Cp}^{*} \mathrm{Co}(\mathrm{CO}) \mathrm{I}_{2}$, which was previously shown by Matsunaga and Kanai to be highly efficient for indole C2-H amidation [50], served as the pre-catalyst (Scheme 4). Hexafluoroisopropanol (HFIP) [51,52] was needed for the C-H allylation, as were acetate salts. The authors interpreted the latter as an indication that the $\mathrm{C}-\mathrm{H}$ activation proceeded via a Concerted-Metalation-Deprotonation (CMD) mechanism [53], as has been elucidated in more detail for second row transition metals $[8,40,54]$. The moderate yield of product $9 \mathbf{a}$ in this reaction was attributed to the weaker coordinating ability of the Weinreb amide group compared to its simpler benzamide relatives or, indeed, to that of the purine $\mathrm{N}_{\mathrm{sp}}^{2}$ centers.

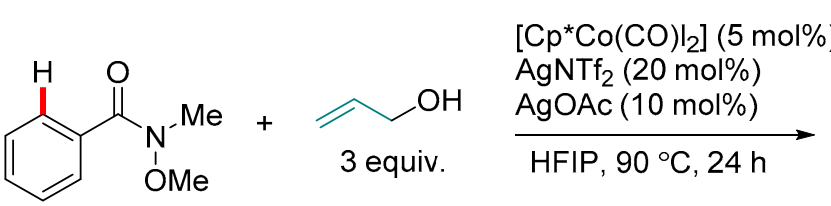

$3 \mathbf{a}$

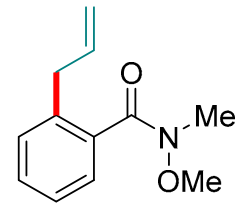

9a, $44 \%$

Scheme 4. An initial example of the Weinreb amide-directed Co(III)-catalyzed ortho-C-H allylation.

In a later study, the group published a considerably expanded range of Co-catalyzed C-H functionalizations using aromatic Weinreb amides (Scheme 5) [55]. These included C-H allylation using allylic carbonates (Scheme 5A), C-H alkenylation under oxidative conditions (Scheme 5B), $\mathrm{C}$-H iodination using $\mathrm{N}$-iodosuccinimide (Scheme 5C) [56] and C-H amidation using dioxazolones (Scheme $5 \mathrm{D})$. These systems relied on similar combinations of $\left[\mathrm{Cp}^{*} \mathrm{Co}(\mathrm{CO}) \mathrm{I}_{2}\right]$ pre-catalyst, a cationic silver additive $\left(\mathrm{AgNTf}_{2}\right.$ or $\left.\mathrm{AgSbF}_{6}\right)$ and $\mathrm{AgOAc}$. Unlike in the Ru-catalyzed case (see Scheme 2), the $\mathrm{N}-\mathrm{O}$ bond of the Weinreb amide moiety was preserved. Competition and kinetic isotope exchange experiments showed that the $\mathrm{C}-\mathrm{H}$ activation event in the case of the allylation reaction was both rate-limiting and all but irreversible, supplying further evidence for the CMD pathway Yoshino and Matsunaga proposed in their earlier study [49]. Their proposed mechanism for the Co(III)-catalyzed $\mathrm{C}-\mathrm{H}$ allylation is shown in Figure 3. In related recent work, Whiteoak and Hamilton have elucidated the mechanistic details governing the oxidative Co-catalyzed C-H alkenylation of amides, and specifically whether and why alkyl or alkenyl products are obtained depending on the choice of alkene substrate [57]. 


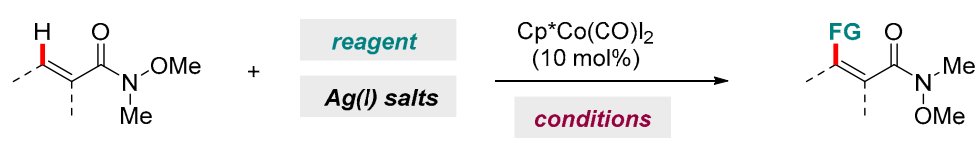

3

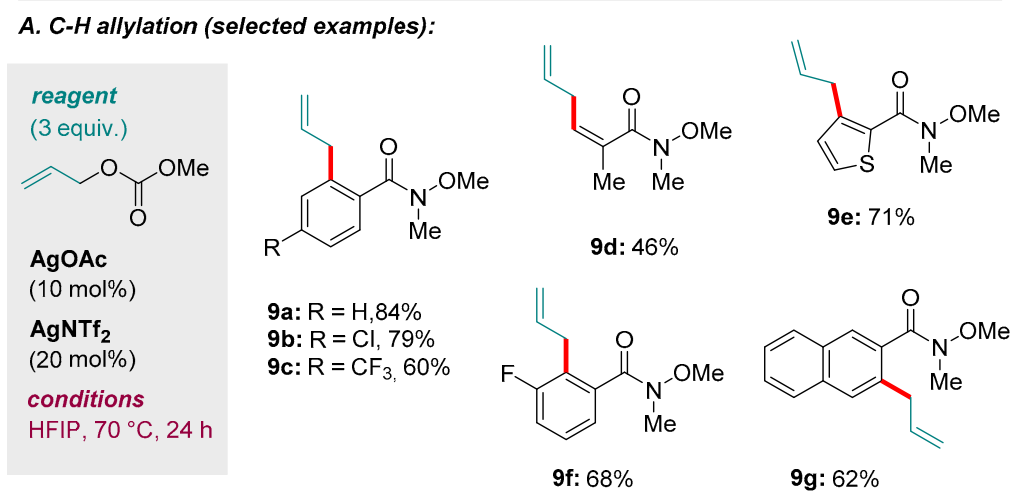

B. C-H alkenylation (selected examples):

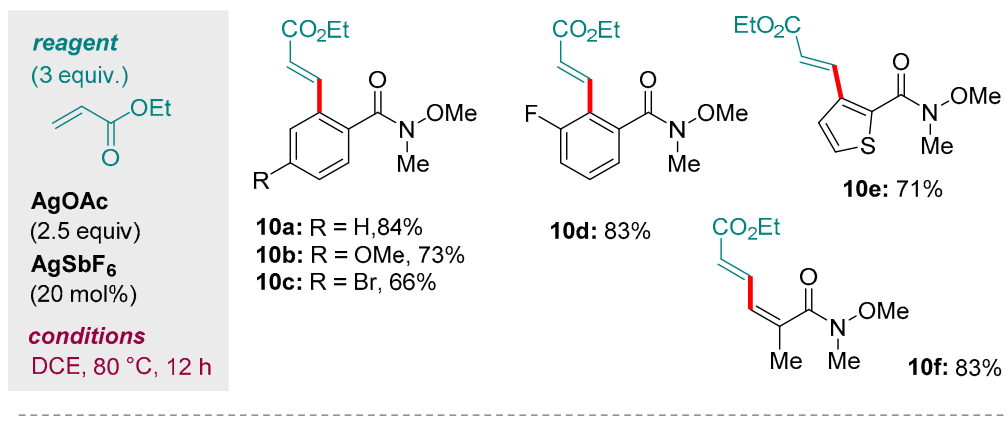

\section{C. $\mathrm{C}-\mathrm{H}$ iodination (selected examples):}

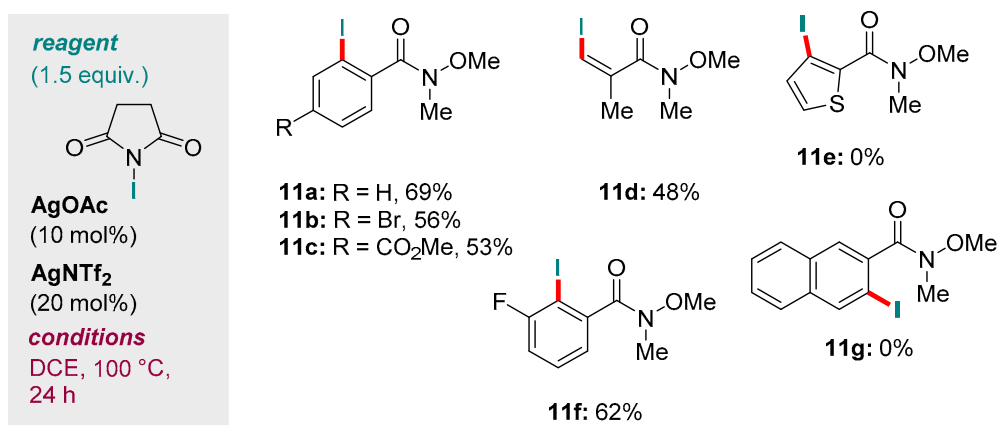

D. C-H amidation (selected examples):

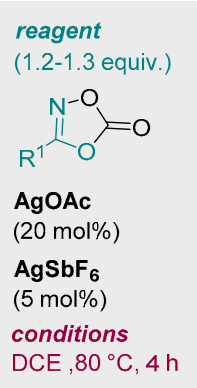

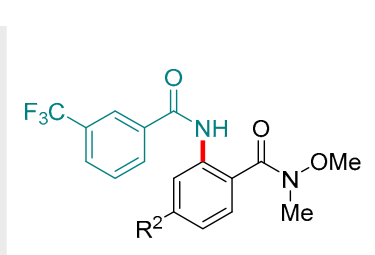

12a: $R^{2}=H, 78 \%$

12b: $R^{2}=$ OMe, $88 \%$

12c: $R^{2}=B r, 68 \%$

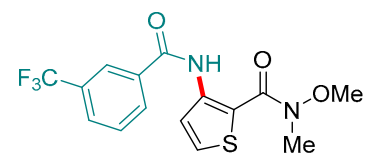

12d: $86 \%$

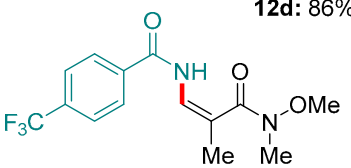

12e: $89 \%$

Scheme 5. Selected examples of C-H transformations enabled by a Co(III)-catalyzed system. 


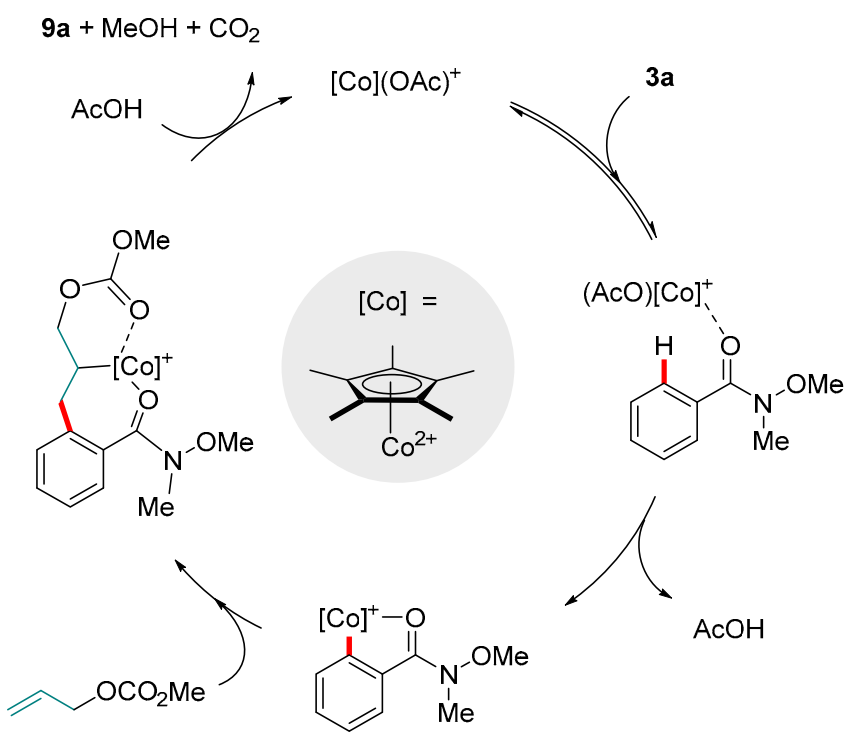

Figure 3. A mechanism proposed by Yoshino and Matsunaga for the Co(III)-catalyzed C-H allylation of Weinreb amides.

The relevance to wider synthetic contexts of the transformations reported by Yoshino and Matsunaga was demonstrated through the conversion of the Weinreb amide group in their various products to the corresponding ketones, aldehydes and alkenes. This thus delivers several motifs whose preparation might otherwise be longer and more demanding.

\section{Pd-catalyzed Reactions}

Palladium is perhaps the most firmly established metal for coupling chemistry [58-62], and this has translated to its high level of popularity for C-H functionalization reactions [16,63-66]. Many Pd-based catalysts are well-defined [67,68], permitting systematic tuning of their properties, and are understood, most usually, to work via $\mathrm{Pd}(0) / \mathrm{Pd}(\mathrm{II})$ or $\mathrm{Pd}(\mathrm{II}) / \mathrm{Pd}(\mathrm{IV})$ manifolds $[62,64,66]$. Despite the prevalence of many ortho-directing groups, including several closely related amides [30], there have been relatively few examples of Pd-catalyzed reactions using Weinreb amides.

In 2015, Wang and co-workers reported the first Weinreb amide-directed C-H functionalization catalyzed by Pd. The reaction took place between either aryl Weinreb amides 3 (Scheme 6a) or benzyl amides 13 and iodoarenes using $\mathrm{Pd}(\mathrm{OAc})_{2}$ as the pre-catalyst in DCE solvent [69]. Both Weinreb types showed high tolerance towards electron-donating and electron-withdrawing substituents, as well as halogens (e.g., the bromide in $\mathbf{1 5 d}$ ). However, benzyl amides showed considerably worse mono-selectivity, except if meta substituents were present (e.g., 15c and 15d) presumably to impart steric hindrance.

(a)
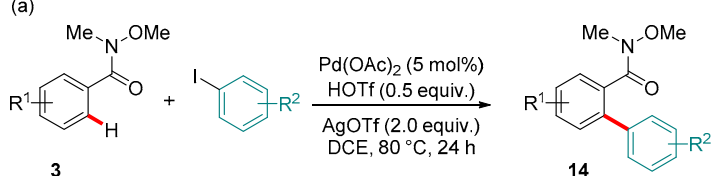

3

14
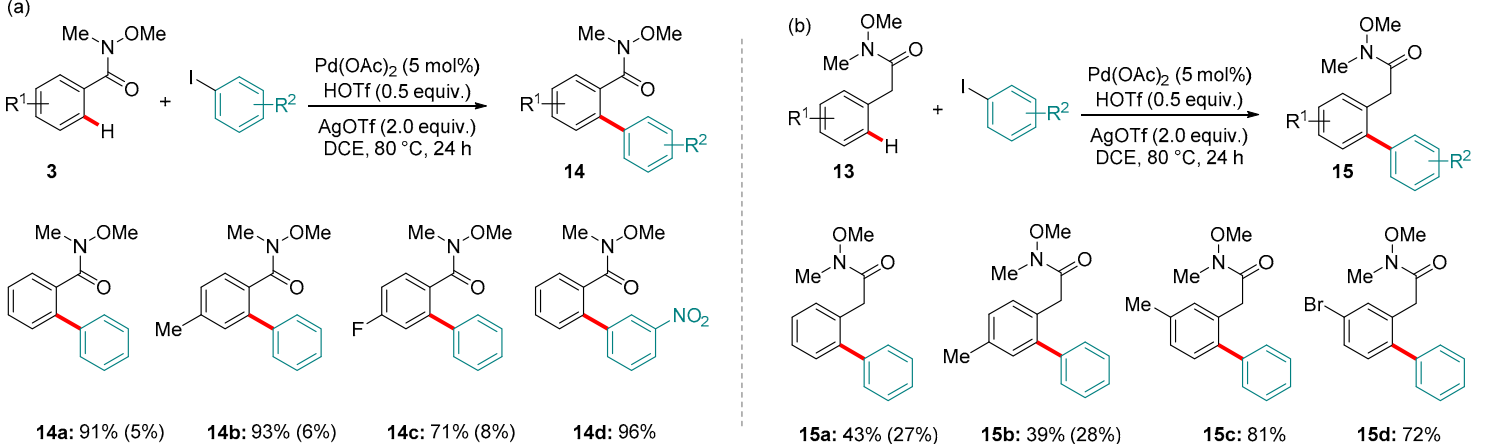

15a: $43 \%(27 \%)$

15b: $39 \%(28 \%)$

15c: $81 \%$

15d: $72 \%$

Scheme 6. Pd-catalyzed C-H arylation of (a) aryl and (b) benzyl amides. Yields in parentheses refer to the amount of di-arylated products detected. 
Figure 4 shows one of the proposed mechanisms, adapted for the specific case of substrate $3 a$. A kinetic isotope effect (KIE) of 1.1 suggested that the C-H activation step itself (forming 16 from 3 ) was not rate-determining. Oxidative addition of the aryl iodide to $\mathbf{1 6}$ was postulated to form $\mathbf{1 7}$ from which the product 14a is formed via reductive elimination. The authors reported that AgOTf, as well as acting as an oxidant, was crucial for the reaction and hypothesized that in situ generated $\operatorname{Pd}(\mathrm{OTf})_{2}$ is a key aspect of the catalytic cycle. (We note that the various roles Ag plays in Pd-catalyzed reactions have recently been reviewed by Pérez-Temprano and co-workers [70].)

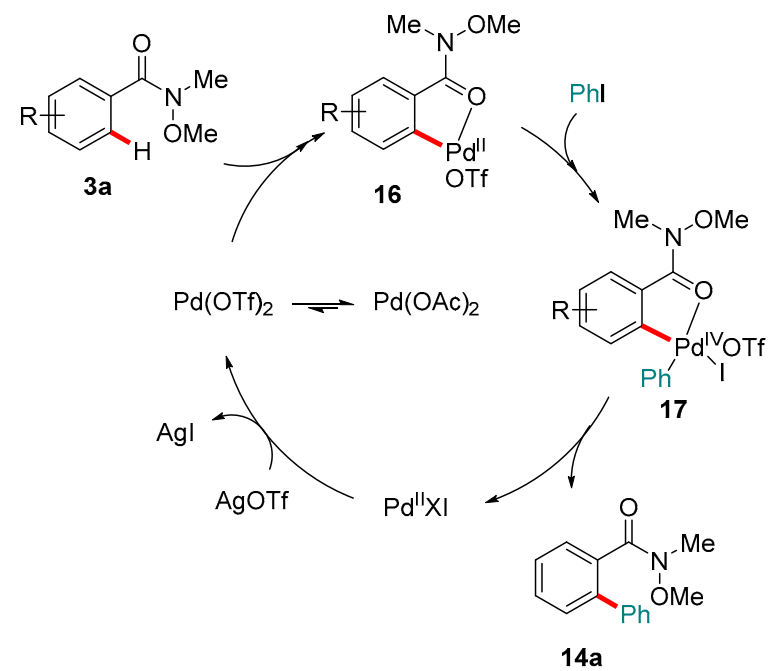

Figure 4. Mechanism proposed by Wang and co-workers for the C-H ortho-arylation of Weinreb amides proceeding via $\mathrm{Pd}(\mathrm{IV})$ intermediates.

To the best of our knowledge, the only other example of a Pd-catalyzed Weinreb amide-directed $\mathrm{C}-\mathrm{H}$ arylation comes from a single entry in a study by Bhanage and workers on the use of anilines as arylating reagents for $\mathrm{N}$-methoxybenzamides (Scheme 7) [71]. Conditions were largely analogous to those described for Wang's reaction above, with the principal exception that aniline underwent in situ oxidation using ${ }^{t} \mathrm{BuONO}$ to generate the electrophilic coupling partner. However, the yield for the Weinreb amide specifically was low, indicating that although this approach holds some promise, it is harder to optimize for the Weinreb amide compared to the using more conventional coupling partners.

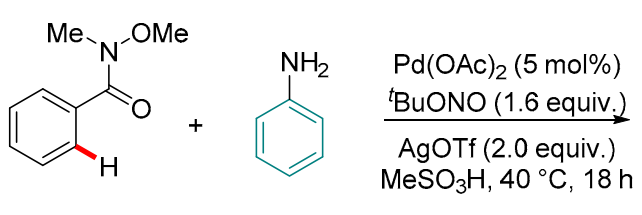

$3 \mathbf{a}$

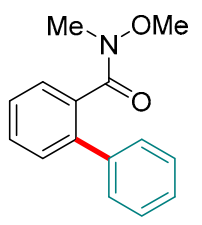

14a: $21 \%$

Scheme 7. Bhanage's C-H arylation using aniline as the electrophile source.

Also in 2015, Yu and co-workers described conditions for the efficient alkenylation and acetoxylation of Weinreb amides (Scheme 8) [72], overcoming the additional entropic penalty imposed by the extra methylene unit present in the directing group (and thus the challenge of forming seven-membered palladacyclic intermediates). In keeping with related protocols reported by $Y u$ and co-workers, the presence of Ac-Gly-OH was found to be crucial to facilitate the C-H functionalization step [73].

$\mathrm{Yu}$ and co-workers found the olefination reaction to have moderate to excellent yields, exclusively mono C-H olefination with ortho and meta-substituted benzyl Weinreb amides, but reduced selectivity if the substituents were positioned para with respect to the directing group (Scheme 8). 
<smiles>[R]c1ccc(CC(=O)N(C)OC)cc1</smiles>

13<smiles>CCOC(=O)C=Cc1ccccc1CC(=O)N(C)OC</smiles>

$18 \mathbf{a}$

$29 \%(58 \%)$<smiles>CCOC(=O)/C=C/c1cccc(C)c1CC(=O)N(C)OC</smiles>

$18 \mathrm{~b}$

$89 \%$<smiles>CCOC(=O)CCc1cc(C)ccc1CC(=O)N(C)OC</smiles>

$18 \mathrm{c}$

$20 \%(47 \%)$

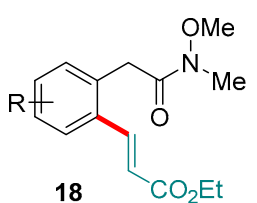

18

Scheme 8. Yu and co-workers' protocol for the oxidative ortho $\mathrm{C}-\mathrm{H}$ acetoxylation of benzylic Weinreb amides. Yields in parentheses refer to the amount of di-olefinated products detected.

The acetoxylation of benzyl amides (Scheme 9) used $\mathrm{PhI}(\mathrm{OAc})_{2}$ as the oxidant in the presence of either $\mathrm{Ac}_{2} \mathrm{O}$ or tert-butyl peroxyacetate $\left(\mathrm{MeC}(\mathrm{O}) \mathrm{OO}^{t} \mathrm{Bu}\right)$. Yields and tolerance towards various substituents were good (examples 19a-c). Furthermore, it was possible to expand the scope by an extra methylene unit (i.e., the reaction can proceed with good efficiency via an 8-membered palladacycle) to give product $19 \mathrm{~d}$.

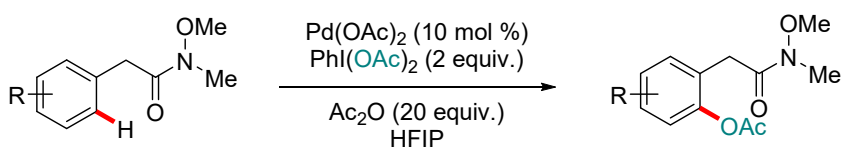

13 $18-48 \mathrm{~h}, 70-90^{\circ} \mathrm{C}$ 19<smiles>CON(C)C(=O)Cc1ccccc1OC(C)=O</smiles>

$19 a$ $70 \%(22 \%)$<smiles>COc1cccc(OC(C)=O)c1CC(=O)N(C)OC</smiles>

$19 b$

$80 \%$<smiles>CON(C)C(=O)Cc1c(Br)cccc1OC(C)=O</smiles>

$19 \mathrm{c}$ $53 \%$<smiles>COC(=O)CCc1ccccc1OC(C)=O</smiles>

19d

$66 \%$

Scheme 9. Yu and co-workers' protocol for the oxidative ortho $\mathrm{C}-\mathrm{H}$ acetoxylation of benzylic Weinreb amides. Yields in parentheses refer to the amount of di-acetoxylated products detected.

The introduction of halogens to organic substrates is an inherently valuable pursuit in methodology development, owing the great versatility of C-halogen bonds in synthesis [74]. In 2017, the group of Kapur disclosed the Pd-catalyzed C-H halogenation (iodination, bromination and chlorination) of Weinreb amides (Scheme 10) [75]. The reaction relied on a combination of $\mathrm{Pd}(\mathrm{OAc})_{2}$ and $\mathrm{Cu}(\mathrm{OTf})_{2}$ with $\mathrm{N}$-halo-succinimide (NXS; $\mathrm{X}=\mathrm{I}, \mathrm{Br}$ or $\mathrm{Cl}$ ) as the halogen source. The reaction worked well with a variety of substituents, except for nitro groups, which switch off the reaction from either of the ortho or para position. 


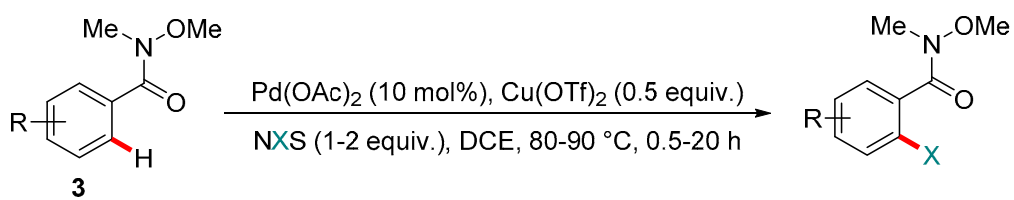<smiles>[X]c1ccccc1C(=O)N(C)OC</smiles>

11a: I $(68 \%)$

20a: $\operatorname{Br}(81 \%)$

21a: $\mathrm{Cl}(62 \%)$<smiles>[X]c1cc(F)ccc1C(=O)N(C)OC</smiles>

11h: I (71\%) 20b: $\operatorname{Br}(68 \%)$<smiles>[X]c1cc(Cl)ccc1C(=O)N(C)OC</smiles>

11i: I $(57 \%)$

20c: $\operatorname{Br}(62 \%)$

21b: $\mathrm{Cl}(49 \%)$<smiles>COc1cccc(C(=O)N(C)C)c1Br</smiles>

20d: $64 \%$

Scheme 10. Kapur and co-workers' reaction for the ortho C-H halogenation of aromatic Weinreb amides.

Mechanistic studies suggested that the $\mathrm{C}-\mathrm{H}$ activation step was irreversible, but not rate-limiting. The catalytic cycle (Figure 5) was proposed to proceed via a route closely related to that of the corresponding arylation reaction (Figure 4, above): carbonyl directed cyclometallation to give 22 precedes oxidative addition into NXS, the latter of which produces $\mathrm{Pd}(\mathrm{IV})$ species 23 (a bimetallic $\mathrm{Pd}(\mathrm{III})$ species [76-79]—not shown—is also possible). Thereafter, reductive elimination releases the desired product.

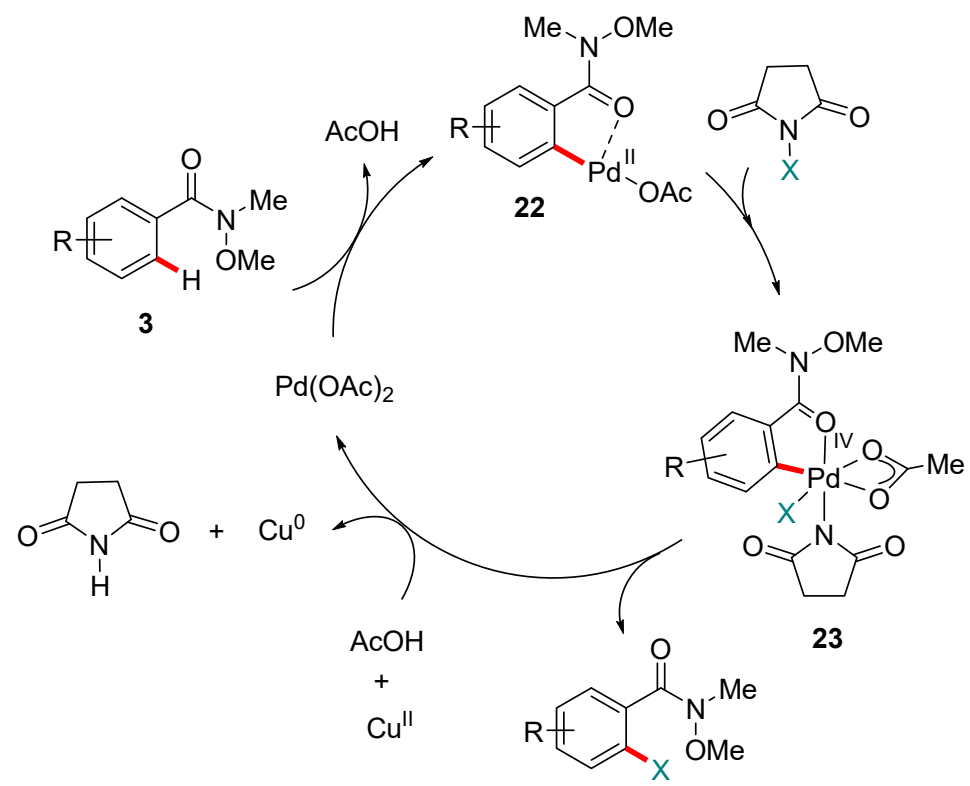

Figure 5. An adapted version of the mechanism proposed by Kapur and co-workers for the Pd-catalyzed ortho C-H halogenation of aromatic Weinreb amides. $\mathrm{X}=\mathrm{Cl}^{-}, \mathrm{Br}^{-}$or $\mathrm{I}^{-}$.

2018 saw Yu and co-workers extend the utility of the Weinreb amide directing group further [80]. This time, the Yu group used it as the basis for directing Pd-catalyzed $\mathrm{C}_{\mathrm{sp}}{ }^{3}-\mathrm{H}$ arylation of alkyl groups (Scheme 11). The discovery of general and efficient methods that allow selective substitution of $\mathrm{C}\left(\mathrm{sp}^{3}\right)-\mathrm{H}$ at transition metal centers is a long-standing challenge. For Pd, progress has been notably rapid in in the past few years [63,81-83], and its various aspects have been reviewed recently $[65,84,85]$. 


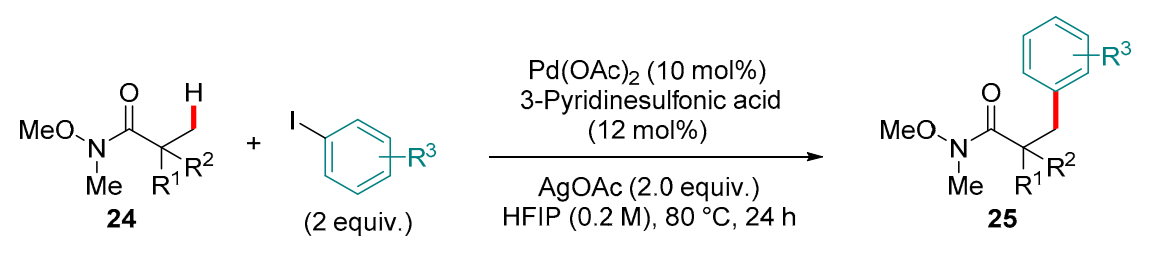<smiles>COC(=O)C(C)(C)Cc1ccc(C(C)=O)cc1</smiles>

25a: 61\% (15\%)<smiles>CC(=O)c1ccc(CC(C)(C)C(=O)N(C)O[Na])cc1</smiles>

25b: $63 \%(5 \%)$<smiles>COC(=O)C(Cc1ccc(C(C)=O)cc1)(c1ccccc1)[N+](=O)[O-]</smiles>

25c: $59 \%$<smiles>COC(=O)C(Cc1ccc(F)cc1)(Cc1ccc(C(C)=O)cc1)C(=O)OC</smiles><smiles>CON(C)C(=O)C1(C)CC1c1ccc(C(C)=O)cc1</smiles>

25e: $97 \%$<smiles>CON(C)C(=O)C1(C)CC1c1ccc(C(F)(F)F)cc1</smiles>

25f: $86 \%$<smiles>CON(C)C(=O)C1(C)CC1c1ccc([N+](=O)[O-])cc1</smiles>

25g: $83 \%$

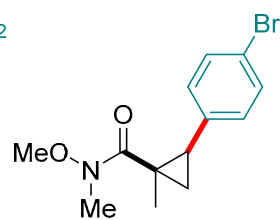

25h: $80 \%$

Scheme 11. Selected scope from $\mathrm{Yu}$ and co-workers' Pd-catalyzed $\mathrm{C}\left(\mathrm{sp}^{3}\right)-\mathrm{H}$ arylation protocol enabled by Weinreb amide directing groups.

$\mathrm{Yu}$ and co-workers found that the inclusion of 3-pyridinesulfonic acid was crucial to the reaction, both Weinreb and other amides. Computational studies at the DFT level revealed that 3-pyridinesulfonic acid stabilizes cationic Pd intermediates during the reaction and that it promotes the dissociation of acetate ligands, which is required for the $\mathrm{C}\left(\mathrm{sp}^{3}\right)-\mathrm{H}$ bond cleavage to occur [80].

\section{Rh-catalyzed Reactions}

The first two decades of this century have seen an explosion of interest in the use of $\mathrm{Rh}(\mathrm{III})$ catalysts for selective C-H functionalization. Substantial progress has been made in both scope $[86,87]$ and attendant mechanistic understanding [7,88-90]. As part of their efforts to answer key questions relating to the regioselectivity of $\mathrm{Rh}$ (III)-catalyzed transformations, Rovis and co-workers reported in 2013 an intramolecular alkene hydroarylation directed by Weinreb amide $\mathbf{2 6}$ in excellent yield (Scheme 12) [91].
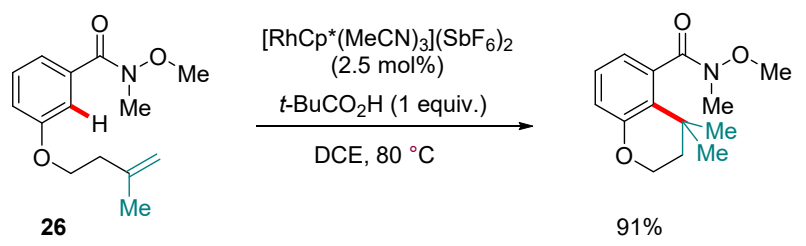

Scheme 12. A Rh(III)-catalyzed, Weinreb amide-directed alkene hydroarylation.

Wang and co-workers reported a closely-related but more elaborate system, involving $\mathrm{Cu}(\mathrm{OAc})_{2}$ as a catalytic oxidant regenerated under air to retain olefin functionality at the end of a cycle coupling aromatic Weinreb amides with alkenes (Scheme 13) [92]. An ample scope demonstrated the reaction's tolerance towards various functional groups, including halogens, various ortho-substituents and a range of electron-donating and electron-withdrawing groups. Competition experiments revealed that electron-rich arenes reacted faster than their electron-poor counterparts. 


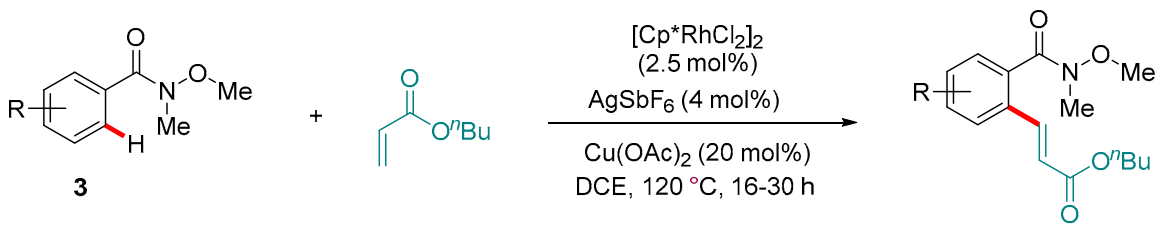<smiles>COC(=O)Cc1cc(Br)ccc1C(=O)N(OC)OC</smiles>

10g: $86 \%^{a, b}$<smiles>CCOC(=O)/C=C/c1cccc(OC)c1C(=O)N(C)OC</smiles>

10h: $78 \%$<smiles>COC(=O)C=Cc1cccc([N+](=O)[O-])c1C(=O)O[Na]</smiles>

10i: $96 \%$<smiles>COC(=O)C=Cc1cc(OC)ccc1C(=O)O[Na]</smiles>

10j: $84 \%$<smiles>COC(=O)C=Cc1cc(C#N)ccc1C(=O)N(OC)OC</smiles>

10k: $89 \%^{a}$<smiles>COC(=O)/C=C/c1cc(C)ccc1C(=O)N(OC)OC</smiles>

10I: $85 \%$<smiles>COC(=O)CCc1cc(-c2ccccc2)ccc1C(=O)N(C)OC</smiles>

10m: $74 \%^{a, b}$

Scheme 13. Selected examples from Wang and co-workers' oxidative Rh-catalyzed C-H alkenylation directed by Weinreb amides. ${ }^{a}\left[\mathrm{Cp}^{*} \mathrm{RhCl}_{2}\right]_{2}(2.5 \mathrm{~mol} \%)$ and $\mathrm{AgSbF}_{6}(10 \mathrm{~mol} \%)$ loadings were used. ${ }^{\mathrm{b}}$ A reaction temperature of $130{ }^{\circ} \mathrm{C}$ was used.

The mechanism proposed by Wang and co-workers (Figure 6) involved coordination of the $\mathrm{Rh}(\mathrm{III})$ center to the carbonyl moiety of the Weinreb amide, insertion of the alkene to the rhodacyclic intermediate (27), $\beta$-hydride elimination and regeneration of the active catalyst by $\mathrm{Cu}(\mathrm{OAc})_{2}$.

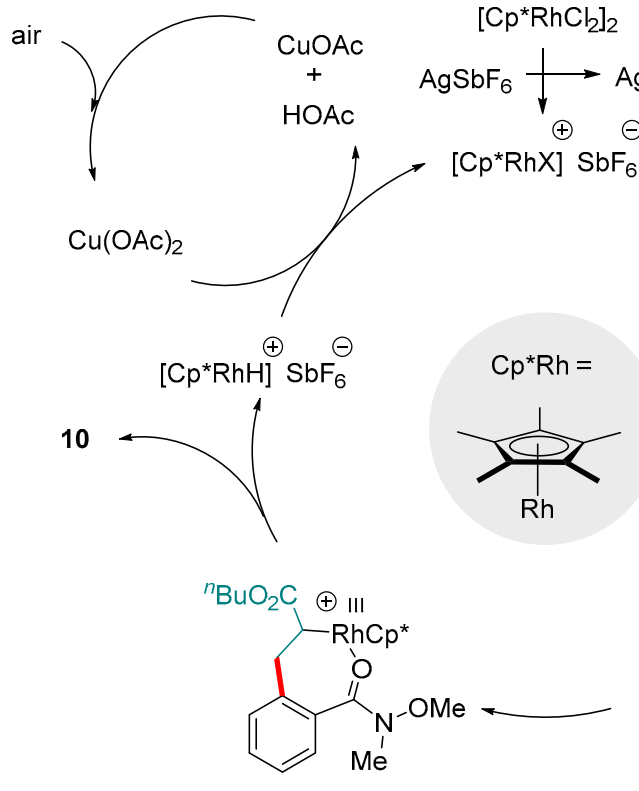

29
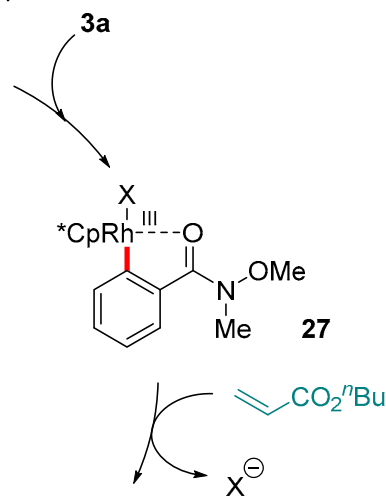

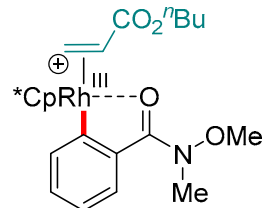

28

Figure 6. An adapted version of the mechanism proposed by Wang and co-workers for the oxidative C-H alkenylation of aromatic Weinreb amides catalyzed by Rh(III). 
Whilst, strictly speaking, it represents a slight departure from the current focus on the Weinreb amide group, it is noteworthy that a very closely related class of substrates, has been used extensively wherein their $\mathrm{C}(\mathrm{O}) \mathrm{NH}-\mathrm{OMe}$ bond as an "internal oxidant" for transition metal centers. Thus, $\mathrm{C}-\mathrm{H}$ functionalization reactions may be performed without exogenous oxidants. This strategy has worked with a number of transition metals, $\mathrm{Rh}(\mathrm{I} / \mathrm{III})$ catalytic cycles have dominated in this area [41].

In 2018, Qin and co-workers disclosed a near identical set of conditions to those used by Wang above, but using ethenesulfonyl fluoride (ESF) as the alkene coupling partner and 1,4-dioxane as the solvent [93]. However, the Qin group further observed that increasing the loading of $\mathrm{AgSbF}_{6}$ to 1 equivalent favored the formation of cyclic lactones. Residual water introduced from the hygroscopic $\mathrm{AgSbF}_{6}$ was proposed to promote the in situ hydrolysis of the Weinreb amide group to account for the lactone formation, though mechanistic work proved inconclusive. In switching away from Weinreb amides to $\mathrm{N}$-methoxybenazmides $(\mathrm{ArC}(\mathrm{O}) \mathrm{NH}-\mathrm{OMe})$, Qin and co-workers were able to cause a similar oxidative cyclization involving insertion of the ESF double bond into the amide $\mathrm{N}-\mathrm{H}$ unit.

Recent years have witnessed the rediscovery and subsequent explosion of interest in functionalizations enabled by photoredox catalysis. The photoexcitation of transition metal complexes serves as a greener and more economically viable method of generating radical intermediates able to initiate a wide range of valuable reactions [94-98]. One application of this is the replacement of terminal oxidants with lighter loadings of a photocatalyst whose oxidative power is obtained via photoexcitation. Rueping and co-workers applied this strategy to demonstrate that the oxidative alkenylation of aromatic amides, including Weinreb amides, is viable using a manifold analogous to that described by Wang's group (see above), but driven by a visible light-regenerated Ru-based photocatalyst, $\left[\mathrm{Ru}(\mathrm{bpy})_{3}\right]\left[\mathrm{PF}_{6}\right]_{2}$ (Scheme 14) $[99,100]$. The protocol is notable not just for its efficiency and high functional group tolerance, but also for the fact that it could be extended to other amides as well as a variety of olefin substrates (various groups $\mathrm{R}^{2}$ ).

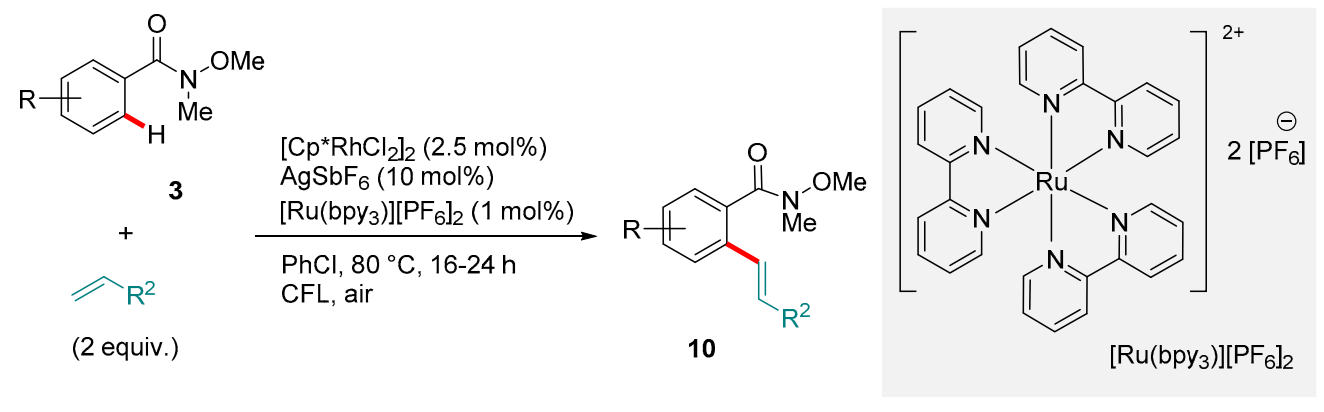

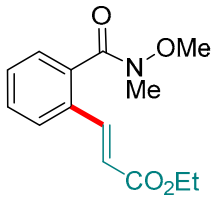

10a: $96 \%$<smiles>COC(=O)C=Nc1cc(Cl)ccc1C(=O)OC</smiles>

$10 \mathrm{n}: 84 \%$

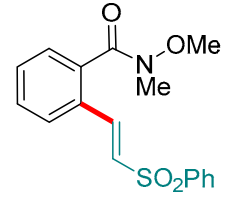

10o: $69 \%$

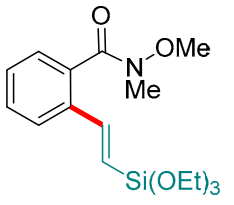

10p: $47 \%$

Scheme 14. Rh-catalyzed olefination of aromatic Weinreb amides enabled by Ru photocatalysis.

The catalytic cycle proposed by Rueping and co-workers closely resembles to that of Wang: ortho-rhodation of 3 to give 29 coordination and insertion of the olefin (complex 30 to 31) and $\beta$-hydride elimination to form the hydride intermediate 32 and the product (Figure 7). Reductive loss of the hydride and re-oxidation to $\mathrm{Rh}(\mathrm{III})$, however, is mediated by the photo-excited $[\mathrm{Ru}(\mathrm{bpy}) 3]^{2+\cdot}$ species, of which only a $1 \mathrm{~mol} \%$ loading is required. 


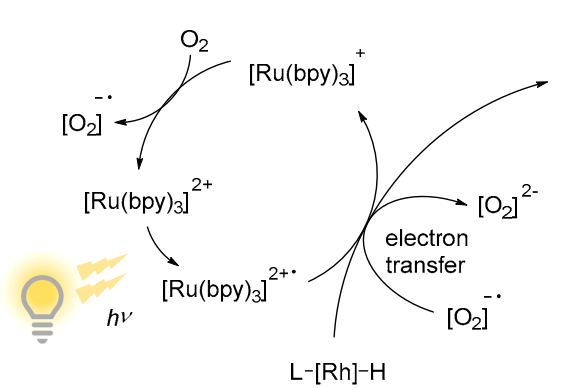

$\mathrm{L}-[\mathrm{Rh}]-\mathrm{H}$

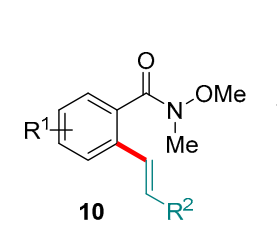

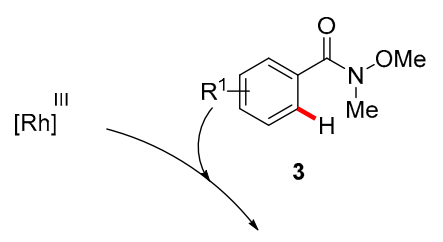<smiles>CN(C)C(=O)c1ccccc1P[InH]</smiles>

29 L

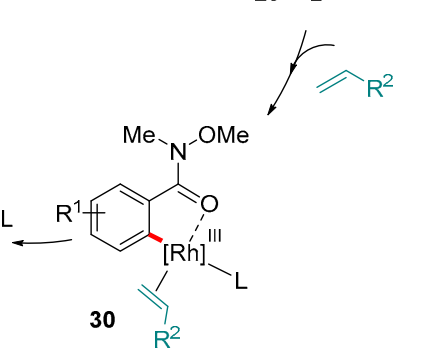

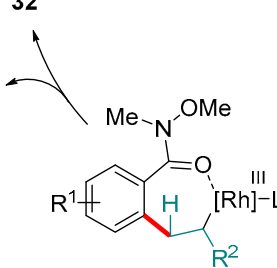

31

Figure 7. Mechanism proposed by Rueping and co-workers for the oxidative C-H olefination of aromatic Weinreb amides catalyzed by $\mathrm{Rh}(\mathrm{III})$ in the presence of a Ru photocatalyst.

\section{Ir-catalyzed Reactions}

Boronates rank amongst the most versatile of groups; they may be converted to an extraordinarily broad range of functionality through a many different mechanisms [101-103]. Moreover, recent years have seen boronate-based methodology emerge as the basis of automated synthesis, which holds enormous potential to streamline the synthesis of many complex (hetero)aromatic and olefinic molecules [104-107]. Such advantages render especially important methods that allow the regioselective introduction of boronates to organic substrates. Amongst these, Ir-catalyzed $\mathrm{C}-\mathrm{H}$ borylation ranks as one of the mildest and most enabling, as it is amenable to regiocontrol through sterics [108,109], directing groups (both to the ortho [110-115] and para [116] positions) and/or the inherent electronic properties [117-119] of a substrate.

Krska, Maleczka and Smith have demonstrated [120] that Weinreb amides rank amongst groups that competently direct Ir catalysts towards ortho-C-H borylation (Scheme 15). Although only a single entry using a Weinreb amide was reported in their Communication, the success of the reaction (a high yield and regioselectivity) was representative, suggesting that other advantages of the method, such as the high functional group tolerance, could easily be paired with the Weinreb amide functionality. Conditions for this transformation deviated little from those commonly used for Ir-catalyzed C-H borylation more generally: $[\operatorname{Ir}(\mu-\mathrm{OMe})(\mathrm{COD})]_{2}$ as the pre-catalyst with dtbtpy as a ligand and $\mathrm{B}_{2}(\mathrm{pin})_{2}$ as the boron source. The corresponding mono-borylated product, 33 was reported to form in $84 \%$ yield.

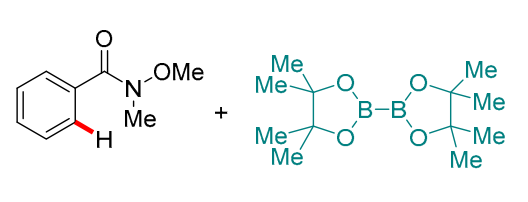

3a

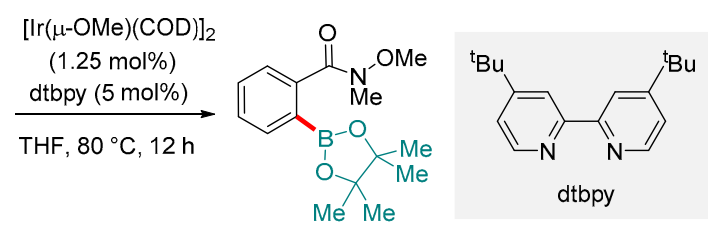

33: $84 \%$

Scheme 15. Ir-catalyzed ortho-C-H borylation of an arene using the Weinreb amide as a directing group.

Enantioselective C-H functionalization marries the benefits of directly substituting a C-H bond with with establishing a new stereocenter in the product. This pursuit continues to inspire a growing body of research [121]. In 2015, Yamamoto and Shirai described an Ir-catalyzed protocol for the asymmetric intermolecular hydroarylation of arenes directed by oxygen based directing 
groups [122]. Although the scope included only a single example exploiting a Weinreb amide directing group (the transformation of $\mathbf{3 4}$ to 35), this entry was representative both in terms of yield and selectivity (Scheme 16). Enantioselectivity was induced using the bidentate bis(phosphoramidite) ligand $(R, R)-S-M e-B I P A M$ ligand (36) and the $\mathrm{N}-\mathrm{O}$ bond was preserved in the product.

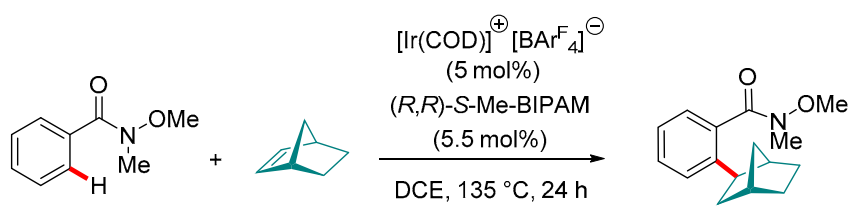

34

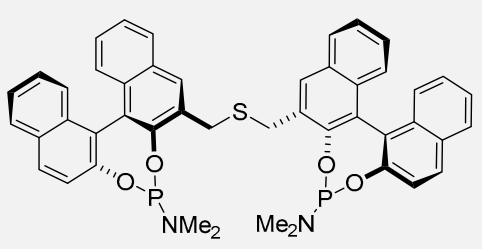

$(R, R)$-S-Me-BIPAM

36
35: $64 \%, 99 \%$ ee

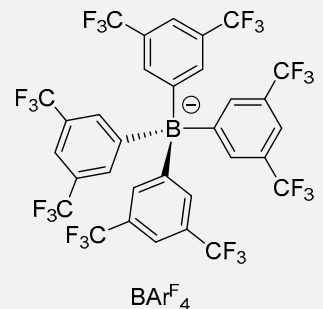

Scheme 16. Ir-catalyzed enantioselective $\mathrm{C}-\mathrm{H}$ hydroarylation of an olefin, directed by a Weinreb amide.

Most recently, the group of Martín-Matute has developed an $\operatorname{Ir}(\mathrm{III})$-catalyzed C-H ortho-iodination of various amides [123]. The scope includes a strong focus on Weinreb amides. Their reaction used $\left[\mathrm{Cp}^{*} \operatorname{Ir}\left(\mathrm{H}_{2} \mathrm{O}\right)_{3}\right]\left[\mathrm{SO}_{4}\right]$ as the catalyst precursor, and $\mathrm{N}$-iodo-succinimide (NIS) as the halogenating reagent in the presence of trifluoroacetic acid. Selected examples are shown below (Scheme 17). It is notable that Weinreb amides returned only the mono-iodinated products 11; a result only tertiary amides gave (primary and secondary amides gave at least small amounts of di-iodination). Whilst the substrate scope included a broad range of functional groups, substituents positioned ortho to the directing group at the outset restricted reactivity, presumably by imposing prohibitive amounts of steric hindrance.

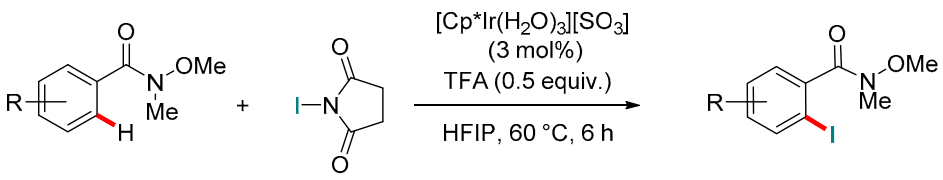

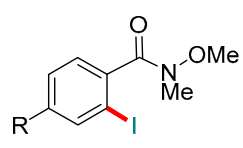

11b, $\mathrm{R}=\mathrm{Br}, 88 \%$ 11c, $\mathrm{R}=\mathrm{CO}_{2} \mathrm{Me}, 78 \%$

$11 \mathrm{~h}, \mathrm{R}=\mathrm{F}, 77 \%$

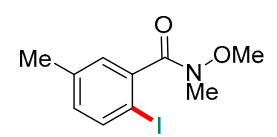

$11 \mathrm{j}: 92 \%(9: 1)^{\mathrm{a}}$

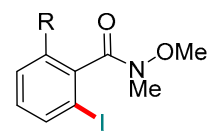

11k: $\mathrm{R}=\mathrm{H}, 92 \%$

11I, $\mathrm{R}=\mathrm{Me}, 0 \%$

$11 \mathrm{~m}, \mathrm{R}=\mathrm{Cl}, 0 \%$

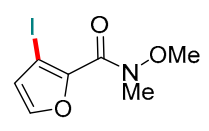

11n: $69 \%$

Scheme 17. Ir-catalyzed C-H iodination of Weinreb amides developed by the Martín-Matute group. ${ }^{\text {a }}$ Ratio of isomers is indicated in parenthesis; the major isomer is shown.

The authors also performed a robustness screen [124,125] to identify the reaction's tolerance towards various functional groups. To this end, various small molecules with different functional groups were added to the reaction mixture to see how the reaction would be affected. Tolerance towards several common functional groups, including ketones amides, carboxylic acids and alkyl halides proved excellent. Aldehydes and alkenes returned less satisfactory results, however. Mechanistically, 
the reaction was proposed to follow a pathway closely related to that of Martín-Matute and co-workers' recently published Ir-catalyzed C-H ortho-iodination of aryl carboxylic acids [126]. The acid additive is understood to play a dual role: 1) activation of NIS via protonation of its carbonyl group and 2) by encouraging the dissociation of the iodinated product from the Ir center. Indeed, Martín-Matute and co-workers found in their optimization study on amides that lowering the amount of acid additive favored the formation of di-iodinated products for non-tertiary amides.

\section{Conclusions}

The Weinreb amide is a privileged functional group in organic synthesis that enables otherwise impossible transformations. Recent developments have seen $\mathrm{C}-\mathrm{H}$ functionalization methodology greatly expand the range of chemical contexts in which its advantages may be exploited. Challenges remain, however. Presently, Weinreb amides are rarely explored as a substrate class in their own right; they are most often presented as specialized examples in studies describing a more general scope, typically amidst other amides. Thus, it is usual that only the simplest examples of Weinreb amides are demonstrated to work under newly developed reaction conditions. This is at least a little unfair since, as some of the examples described above demonstrate, Weinreb amides may return different results to other amides, for example by virtue of the reactivity of their $\mathrm{N}-\mathrm{O}$ bond. Weinreb amides might, in this sense, be considered hitherto as "sleeper" substrates.

Despite this, it is evident that Weinreb amides can direct a wide range of $\mathrm{C}-\mathrm{H}$ functionalization reactions catalyzed by transition metals. $\mathrm{C}-\mathrm{H}$ functionalization, and catalytic methodology in general, is undergoing a shift of emphasis towards the use of less "endangered" [127,128], especially first-row transition elements for catalysis [43]. However, their use with Weinreb amides is rare. For example, to the best of our knowledge, no Weinreb amide-directed $\mathrm{C}-\mathrm{H}$ functionalization reactions catalyzed by $\mathrm{Mn}, \mathrm{Fe}$ or Ni have yet been reported.

Finally, it is unfortunate that the preponderance of conditions used for Weinreb amide directed $\mathrm{C}-\mathrm{H}$ functionalization involve toxic halogenated solvents. Increasing legislative pressure is being brought to bear on this problem, with a particular focus against 1,2-dichloroethane (DCE) [129], which features in many of the reactions discussed above. We look forward to the use of Weinreb amides under greener conditions [130-132].

Acknowledgments: We thank the Wenner-Gren Foundation for funding (JK).

Conflicts of Interest: The authors declare that no conflicts of interest exist.

\section{References}

1. Crabtree, R.H.; Lei, A. Introduction: CH Activation. Chem. Rev. 2017, 117, 8481-8482. [CrossRef] [PubMed]

2. Yang, Y.; Lan, J.; You, J. Oxidative C-H/C-H Coupling Reactions between Two (Hetero)arenes. Chem. Rev. 2017, 117, 8787-8863. [CrossRef] [PubMed]

3. Park, Y.; Kim, Y.; Chang, S. Transition Metal-Catalyzed C-H Amination: Scope, Mechanism, and Applications. Chem. Rev. 2017, 117, 9247-9301. [CrossRef] [PubMed]

4. Murakami, K.; Yamada, S.; Kaneda, T.; Itami, K. C-H Functionalization of Azines. Chem. Rev. 2017, 117, 9302-9332. [CrossRef] [PubMed]

5. Sandtorv, A.H. Transition Metal-Catalyzed C-H Activation of Indoles. ACS Catal. 2015, 357, $2403-2435$. [CrossRef]

6. Simmons, E.M.; Hartwig, J.F. On the Interpretation of Deuterium Kinetic Isotope Effects in C-H Bond Functionalizations by Transition-Metal Complexes. Angew. Chem. Int. Ed. Engl. 2012, 51, 3066-3072. [CrossRef] [PubMed]

7. Qi, X.; Li, Y.; Bai, R.; Lan, Y. Mechanism of Rhodium-Catalyzed C-H Functionalization: Advances in Theoretical Investigation. Acc. Chem. Res. 2017, 50, 2799-2808. [CrossRef] [PubMed]

8. Davies, D.L.; Macgregor, S.A.; McMullin, C.L. Computational Studies of Carboxylate-Assisted C-H Activation and Functionalization at Group 8-10 Transition Metal Centers. Chem. Rev. 2017, 117, 8649-8709. [CrossRef] [PubMed] 
9. Balcells, D.; Clot, E.; Eisenstein, O. C-H Bond Activation in Transition Metal Species from a Computational Perspective. Chem. Rev. 2010, 110, 749-823. [CrossRef] [PubMed]

10. Gensch, T.; Hopkinson, M.N.; Glorius, F.; Wencel-Delord, J. Mild metal-catalyzed C-H activation: Examples and concepts. Chem. Soc. Rev. 2016, 45, 2900-2936. [CrossRef] [PubMed]

11. Hartwig, J.F.; Larsen, M.A. Undirected, Homogeneous C-H Bond Functionalization: Challenges and Opportunities. ACS Cent. Sci. 2016, 2, 281-292. [CrossRef] [PubMed]

12. Brückl, T.; Baxter, R.D.; Ishihara, Y.; Baran, P.S. Innate and Guided C-H Functionalization Logic. Acc. Chem. Res. 2012, 45, 826-839. [CrossRef] [PubMed]

13. Ping, L.; Chung, D.S.; Bouffard, J.; Lee, S.G. Transition metal-catalyzed site- and regio-divergent C-H bond functionalization. Chem. Soc. Rev. 2017, 46, 4299-4328. [CrossRef] [PubMed]

14. Saint-Denis, T.G.; Zhu, R.-Y.; Chen, G.; Wu, Q.-F.; Yu, J.-Q. Enantioselective C(sp3)-H bond activation by chiral transition metal catalysts. Science 2018, 359, eaao4798. [CrossRef] [PubMed]

15. Sambiagio, C.; Schönbauer, D.; Blieck, R.; Dao-Huy, T.; Pototschnig, G.; Schaaf, P.; Wiesinger, T.; Zia, M.F.; Wencel-Delord, J.; Besset, T.; et al. A comprehensive overview of directing groups applied in metal-catalysed C-H functionalisation chemistry. Chem. Soc. Rev. 2018, 47, 6603-6743. [CrossRef] [PubMed]

16. Lyons, T.W.; Sanford, M.S. Palladium-Catalyzed Ligand-Directed C-H Functionalization Reactions. Chem. Rev. 2010, 110, 1147-1169. [CrossRef] [PubMed]

17. Dey, A.; Agasti, S.; Maiti, D. Palladium catalysed meta-C-H functionalization reactions. Org. Biomol. Chem. 2016, 14, 5440-5453. [CrossRef] [PubMed]

18. Leitch, J.A.; Frost, C.G. Ruthenium-catalysed $\sigma$-activation for remote meta-selective C-H functionalisation. Chem. Soc. Rev. 2017, 46, 7145-7153. [CrossRef] [PubMed]

19. Dey, A.; Maity, S.; Maiti, D. Reaching the south: Metal-catalyzed transformation of the aromatic para-position. Chem. Commun. 2016, 52, 12398-12414. [CrossRef] [PubMed]

20. Rousseau, G.; Breit, B. Removable Directing Groups in Organic Synthesis and Catalysis. Angew. Chem. Int. Ed. 2011, 50, 2450-2494. [CrossRef] [PubMed]

21. Yadav, M.R.; Rit, R.K.; Shankar, M.; Sahoo, A.K. Reusable and Removable Directing Groups for $\mathrm{C}\left(\mathrm{sp}^{2}\right)-\mathrm{H}$ Bond Functionalization of Arenes. ASIAN J. Org. Chem. 2015, 4, 846-864. [CrossRef]

22. Zhang, F.; Spring, D.R. Arene C-H functionalisation using a removable/modifiable or a traceless directing group strategy. Chem. Soc. Rev. 2014, 43, 6906-6919. [CrossRef] [PubMed]

23. Font, M.; Quibell, J.M.; Perry, G.J.P.; Larrosa, I. The use of carboxylic acids as traceless directing groups for regioselective C-H bond functionalisation. Chem. Commun. 2017, 53, 5584-5597. [CrossRef] [PubMed]

24. Gandeepan, P.; Ackermann, L. Transient Directing Groups for Transformative C-H Activation by Synergistic Metal Catalysis. Chem 2018, 4, 199-222. [CrossRef]

25. Ihara, H.; Koyanagi, M.; Suginome, M. Anthranilamide: A Simple, Removable ortho-Directing Modifier for Arylboronic Acids Serving also as a Protecting Group in Cross-Coupling Reactions. Org. Lett. 2011, 13, 2662-2665. [CrossRef] [PubMed]

26. Ihara, H.; Suginome, M. Easily Attachable and Detachable ortho-Directing Agent for Arylboronic Acids in Ruthenium-Catalyzed Aromatic C-H Silylation. J. Am. Chem. Soc. 2009, 131, 7502-7503. [CrossRef] [PubMed]

27. Ihara, H.; Ueda, A.; Suginome, M. Ruthenium-catalyzed C-H Silylation of Methylboronic Acid Using a Removable \&alpha;-Directing Modifier on the Boron Atom. Chem. Lett. 2011, 40, 916-918. [CrossRef]

28. Yamamoto, T.; Ishibashi, A.; Suginome, M. Regioselective Synthesis of o-Benzenediboronic Acids via Ir-Catalyzed o-C-H Borylation Directed by a Pyrazolylaniline-Modified Boronyl Group. Org. Lett. 2017, 19, 886-889. [CrossRef] [PubMed]

29. Zhao, Q.; Poisson, T.; Pannecoucke, X.; Besset, T. The Transient Directing Group Strategy: A New Trend in Transition-Metal-Catalyzed C-H Bond Functionalization. Synthesis 2017, 49, 4808-4826. [CrossRef]

30. Zhu, R.-Y.; Farmer, M.E.; Chen, Y.-Q.; Yu, J.-Q. A Simple and Versatile Amide Directing Group for C-H Functionalizations. Angew. Chem. Int. Ed. 2016, 55, 10578-10599. [CrossRef] [PubMed]

31. Nahm, S.; Weinreb, S.M. N-methoxy-n-methylamides as effective acylating agents. Tetrahedron Lett. 1981, 22, 3815-3818. [CrossRef]

32. Nowak, M. Weinreb Amides. Synlett 2015, 26, 561-562. [CrossRef]

33. De Sarkar, S.; Liu, W.; Kozhushkov, S.I.; Ackermann, L. Weakly Coordinating Directing Groups for Ruthenium(II)- Catalyzed C-H Activation. Adv. Synth. Catal. 2014, 356, 1461-1479. [CrossRef] 
34. Arockiam, P.B.; Bruneau, C.; Dixneuf, P.H. Ruthenium(II)-catalyzed C-H bond activation and functionalization. Chem. Rev. 2012, 112, 5879-5918. [CrossRef] [PubMed]

35. Ruiz, S.; Villuendas, P.; Urriolabeitia, E.P. Ru-catalysed C-H functionalisations as a tool for selective organic synthesis. Tetrahedron Lett. 2016, 57, 3413-3432. [CrossRef]

36. Yang, F.; Ackermann, L. Ruthenium-Catalyzed C-H Oxygenation on Aryl Weinreb Amides. Org. Lett. 2013, 15, 718-720. [CrossRef] [PubMed]

37. More, N.Y.; Padala, K.; Jeganmohan, M. Ruthenium-Catalyzed C-H Benzoxylation of tert-Benzamides with Aromatic Acids by Weak Coordination. J. Org. Chem. 2017, 82, 12691-12700. [CrossRef] [PubMed]

38. Das, R.; Kapur, M. Fujiwara-Moritani Reaction of Weinreb Amides using a Ruthenium-Catalyzed C-H Functionalization Reaction. Chem. Asian J. 2015, 10, 1505-1512. [CrossRef] [PubMed]

39. Ferreira, E.M.; Zhang, H.; Stoltz, B.M. Oxidative Heck-Type Reactions (Fujiwara-Moritani Reactions). In The Mizoroki-Heck Reaction; Oestreich, M., Ed.; Wiley: Chichester, UK, 2009.

40. Ackermann, L. Carboxylate-Assisted Transition-Metal-Catalyzed C-H Bond Functionalizations: Mechanism and Scope. Chem. Rev. 2011, 111, 1315-1345. [CrossRef] [PubMed]

41. Mo, J.; Wang, L.; Liu, Y.; Cui, X. Transition-Metal-Catalyzed Direct C-H Functionalization under External-Oxidant-Free Conditions. Synthesis 2015, 47, 439-459. [CrossRef]

42. Das, R.; Kapur, M. Product Control using Substrate Design: Ruthenium-Catalysed Oxidative C-H Olefinations of Cyclic Weinreb Amides. Chem. Eur. J. 2016, 22, 16986-16990. [CrossRef] [PubMed]

43. Gandeepan, P.; Müller, T.; Zell, D.; Cera, G.; Warratz, S.; Ackermann, L. 3d Transition Metals for C-H Activation. Chem. Rev. 2018. [CrossRef] [PubMed]

44. Moselage, M.; Li, J.; Ackermann, L. Cobalt-Catalyzed C-H Activation. ACS Catal. 2016, 6, 498-525. [CrossRef]

45. Gao, K.; Yoshikai, N. Low-Valent Cobalt Catalysis: New Opportunities for C-H Functionalization. Acc. Chem. Res. 2014, 47, 1208-1219. [CrossRef] [PubMed]

46. Yoshikai, N. Development of Cobalt-Catalyzed C-H Bond Functionalization Reactions. Bull. Chem. Soc. Jpn. 2014, 87, 843-857. [CrossRef]

47. Yoshino, T.; Ikemoto, H.; Matsunaga, S.; Kanai, M. Cp*CoIII-Catalyzed C2-Selective Addition of Indoles to Imines. Chem. A Eur. J. 2013, 19, 9142-9146. [CrossRef] [PubMed]

48. Yoshino, T.; Ikemoto, H.; Matsunaga, S.; Kanai, M. A Cationic High-Valent Cp*CoIII Complex for the Catalytic Generation of Nucleophilic Organometallic Species: Directed C-H Bond Activation. Angew. Chem. Int. Ed. Engl. 2013, 52, 2207-2211. [CrossRef] [PubMed]

49. Bunno, Y.; Murakami, N.; Suzuki, Y.; Kanai, M.; Yoshino, T.; Matsunaga, S. Cp*CoIII-Catalyzed Dehydrative C-H Allylation of 6-Arylpurines and Aromatic Amides Using Allyl Alcohols in Fluorinated Alcohols. Org. Lett. 2016, 18, 2216-2219. [CrossRef] [PubMed]

50. Sun, B.; Yoshino, T.; Matsunaga, S.; Kanai, M. Air-Stable Carbonyl(pentamethylcyclopentadienyl)cobalt Diiodide Complex as a Precursor for Cationic (Pentamethylcyclopentadienyl)cobalt(III) Catalysis: Application for Directed C-2 Selective C-H Amidation of Indoles. Adv. Synth. Catal. 2014, 356, 1491-1495. [CrossRef]

51. Colomer, I.; Chamberlain, A.E.R.; Haughey, M.B.; Donohoe, T.J. Hexafluoroisopropanol as a highly versatile solvent. Nat. Rev. Chem. 2017, 1, 0088. [CrossRef]

52. Wencel-Delord, J.; Colobert, F. A remarkable solvent effect of fluorinated alcohols on transition metal catalysed C-H functionalizations. Org. Chem. Front. 2016, 3, 394-400. [CrossRef]

53. Planas, O.; Chirila, P.G.; Whiteoak, C.J.; Ribas, X. Current Mechanistic Understanding of Cobalt-Catalyzed C-H Functionalization. Adv. Organomet. Chem. 2018, 69, 209-282. [CrossRef]

54. Gorelsky, S.I.; Lapointe, D.; Fagnou, K. Analysis of the Concerted Metalation-Deprotonation Mechanism in Palladium-Catalyzed Direct Arylation Across a Broad Range of Aromatic Substrates. J. Am. Chem. Soc. 2008, 130, 10848-10849. [CrossRef] [PubMed]

55. Kawai, K.; Bunno, Y.; Yoshino, T.; Matsunaga, S. Weinreb Amide Directed Versatile C-H Bond Functionalization under (eta(5)-Pentamethylcyclopentadienyl)cobalt(III) Catalysis. Chem. Eur. J. 2018, 24, 10231-10237. [CrossRef] [PubMed]

56. Kuhl, N.; Schröder, N.; Glorius, F. Rh(III)-Catalyzed Halogenation of Vinylic C-H Bonds: Rapid and General Access to Z-Halo Acrylamides. Org. Lett. 2013, 15, 3860-3863. [CrossRef] [PubMed] 
57. Chirila, P.G.; Adams, J.; Dirjal, A.; Hamilton, A.; Whiteoak, C.J. Cp*Co(III)-Catalyzed Coupling of Benzamides with $\alpha, \beta$-Unsaturated Carbonyl Compounds: Preparation of Aliphatic Ketones and Azepinones. Chem. Eur. J. 2018, 24, 3584-3589. [CrossRef] [PubMed]

58. Johansson Seechurn, C.C.C.; Kitching, M.O.; Colacot, T.J.; Snieckus, V. Palladium-Catalyzed Cross-Coupling: A Historical Contextual Perspective to the 2010 Nobel Prize. Angew. Chem. Int. Ed. Engl. 2012, 51, 5062-5085. [CrossRef] [PubMed]

59. Wu, X.-F.; Neumann, H.; Beller, M. Synthesis of Heterocycles via Palladium-Catalyzed Carbonylations. Chem. Rev. 2013, 113, 1-35. [CrossRef] [PubMed]

60. Wang, D.; Weinstein, A.B.; White, P.B.; Stahl, S.S. Ligand-Promoted Palladium-Catalyzed Aerobic Oxidation Reactions. Chem. Rev. 2018, 118, 2636-2679. [CrossRef] [PubMed]

61. Ruiz-Castillo, P.; Buchwald, S.L. Applications of Palladium-Catalyzed C-N Cross-Coupling Reactions. Chem. Rev. 2016, 116, 12564-12649. [CrossRef] [PubMed]

62. Sehnal, P.; Taylor, R.J.K.; Fairlamb, I.J.S. Emergence of Palladium(IV) Chemistry in Synthesis and Catalysis. Chem. Rev. 2010, 110, 824-889. [CrossRef] [PubMed]

63. Timsina, Y.N.; Gupton, B.F.; Ellis, K.C. Palladium-Catalyzed C-H Amination of C(sp $\left.{ }^{2}\right)$ and C(sp $\left.{ }^{3}\right)-H$ Bonds: Mechanism and Scope for N-Based Molecule Synthesis. ACS Catal. 2018, 8, 5732-5776. [CrossRef]

64. Topczewski, J.J.; Sanford, M.S. Carbon-hydrogen $(\mathrm{C}-\mathrm{H})$ bond activation at PdIV: A Frontier in C-H functionalization catalysis. Chem. Sci. 2015, 6, 70-76. [CrossRef] [PubMed]

65. He, J.; Wasa, M.; Chan, K.S.L.; Shao, Q.; Yu, J.-Q. Palladium-Catalyzed Transformations of Alkyl C-H Bonds. Chem. Rev. 2017, 117, 8754-8786. [CrossRef] [PubMed]

66. Bonney, K.J.; Schoenebeck, F. Experiment and computation: A combined approach to study the reactivity of palladium complexes in oxidation states 0 to iv. Chem. Soc. Rev. 2014, 43, 6609-6638. [CrossRef] [PubMed]

67. Valente, C.; Çalimsiz, S.; Hoi, K.H.; Mallik, D.; Sayah, M.; Organ, M.G. The Development of Bulky Palladium NHC Complexes for the Most-Challenging Cross-Coupling Reactions. Angew. Chem. Int. Ed. Engl. 2012, 51, 3314-3332. [CrossRef] [PubMed]

68. Hazari, N.; Melvin, P.R.; Beromi, M.M. Well-defined nickel and palladium precatalysts for cross-coupling. Nat. Rev. Chem. 2017, 1, 0025. [CrossRef] [PubMed]

69. Wang, Y.; Zhou, K.; Lan, Q.; Wang, X.-S. Pd(II)-catalyzed C-H arylation of aryl and benzyl Weinreb amides. Org. Biomol. Chem. 2015, 13, 353-356. [CrossRef] [PubMed]

70. Mudarra, Á.L.; Martínez de Salinas, S.; Pérez-Temprano, M.H. Beyond the traditional roles of Ag in catalysis: The transmetalating ability of organosilver(i) species in Pd-catalysed reactions. Org. Biomol. Chem. 2018, 17, 1655-1667. [CrossRef] [PubMed]

71. Yedage, S.L.; Bhanage, B.M. Palladium-Catalyzed Deaminative Phenanthridinone Synthesis from Aniline via C-H Bond Activation. J. Org. Chem. 2016, 81, 4103-4111. [CrossRef] [PubMed]

72. Li, G.; Wan, L.; Zhang, G.; Leow, D.; Spangler, J.; Yu, J.-Q. Pd(II)-Catalyzed C-H Functionalizations Directed by Distal Weakly Coordinating Functional Groups. J. Am. Chem. Soc. 2015, 137, 4391-4397. [CrossRef] [PubMed]

73. Engle, K.M.; Wang, D.-H.; Yu, J.-Q. Ligand-Accelerated C-H Activation Reactions: Evidence for a Switch of Mechanism. J. Am. Chem. Soc. 2010, 132, 14137-14151. [CrossRef] [PubMed]

74. Das, R.; Kapur, M. Transition-Metal-Catalyzed Site-Selective C-H Halogenation Reactions. Asian J. Org. Chem. 2018, 7, 1524-1541. [CrossRef]

75. Das, R.; Kapur, M. Palladium-Catalyzed, ortho-Selective C-H Halogenation of Benzyl Nitriles, Aryl Weinreb Amides, and Anilides. J. Org. Chem. 2017, 82, 1114-1126. [CrossRef] [PubMed]

76. Powers, D.C.; Lee, E.; Ariafard, A.; Sanford, M.S.; Yates, B.F.; Canty, A.J.; Ritter, T. Connecting Binuclear Pd(III) and Mononuclear Pd(IV) Chemistry by Pd-Pd Bond Cleavage. J. Am. Chem. Soc. 2012, 134, 12002-12009. [CrossRef] [PubMed]

77. Powers, D.C.; Benitez, D.; Tkatchouk, E.; Goddard, W.A.; Ritter, T. Bimetallic Reductive Elimination from Dinuclear Pd(III) Complexes. J. Am. Chem. Soc. 2010, 132, 14092-14103. [CrossRef] [PubMed]

78. Powers, D.C.; Ritter, T. Bimetallic Pd(III) complexes in palladium-catalysed carbon-heteroatom bond formation. Nat. Chem. 2009, 1, 419. [CrossRef]

79. Powers, D.C.; Geibel, M.A.L.; Klein, J.E.M.N.; Ritter, T. Bimetallic Palladium Catalysis: Direct Observation of Pd(III)-Pd(III) Intermediates. J. Am. Chem. Soc. 2009, 131, 17050-17051. [CrossRef] [PubMed] 
80. Park, H.; Chekshin, N.; Shen, P.-X.; Yu, J.-Q. Ligand-Enabled, Palladium-Catalyzed $\beta-C(s p 3)-H$ Arylation of Weinreb Amides. ACS Catal. 2018, 8, 9292-9297. [CrossRef]

81. Willcox, D.; Chappell, B.G.N.; Hogg, K.F.; Calleja, J.; Smalley, A.P.; Gaunt, M.J. A general catalytic $\beta-C-H$ carbonylation of aliphatic amines to $\beta$-lactams. Science 2016, 354, 851-857. [CrossRef] [PubMed]

82. Zhu, R.-Y.; Li, Z.-Q.; Park, H.S.; Senanayake, C.H.; Yu, J.-Q. Ligand-Enabled $\gamma-C(s p 3)-H$ Activation of Ketones. J. Am. Chem. Soc. 2018, 140, 3564-3568. [CrossRef] [PubMed]

83. Zhu, R.-Y.; He, J.; Wang, X.-C.; Yu, J.-Q. Ligand-Promoted Alkylation of C(sp3)-H and C(sp2)-H Bonds. J. Am. Chem. Soc. 2014, 136, 13194-13197. [CrossRef] [PubMed]

84. Baudoin, O. Ring Construction by Palladium(0)-Catalyzed C(sp3)-H Activation. Acc. Chem. Res. 2017, 50, 1114-1123. [CrossRef] [PubMed]

85. Baudoin, O. Transition metal-catalyzed arylation of unactivated C(sp3)-H bonds. Chem. Soc. Rev. 2011, 40, 4902-4911. [CrossRef] [PubMed]

86. Chatani, N.; Rej, S. Rh-Catalyzed Removable Directing Group Assisted sp2 or sp3-C-H Bond Functionalization. Angew. Chem. Int. Ed. 2018. [CrossRef]

87. Colby, D.A.; Bergman, R.G.; Ellman, J.A. Rhodium-Catalyzed C-C Bond Formation via Heteroatom-Directed C-H Bond Activation. Chem. Rev. 2010, 110, 624-655. [CrossRef] [PubMed]

88. Vásquez-Céspedes, S.; Wang, X.; Glorius, F. Plausible Rh(V) Intermediates in Catalytic C-H Activation Reactions. ACS Catal. 2018, 8, 242-257. [CrossRef]

89. Davies, D.L.; Ellul, C.E.; Macgregor, S.A.; McMullin, C.L.; Singh, K. Experimental and DFT Studies Explain Solvent Control of C-H Activation and Product Selectivity in the Rh(III)-Catalyzed Formation of Neutral and Cationic Heterocycles. J. Am. Chem. Soc. 2015, 137, 9659-9669. [CrossRef] [PubMed]

90. Li, J.; Qiu, Z. DFT Studies on the Mechanism of the Rhodium(III)-Catalyzed C-H Activation of N-Phenoxyacetamide. J. Org. Chem. 2015, 80, 10686-10693. [CrossRef] [PubMed]

91. Davis, T.A.; Hyster, T.K.; Rovis, T. Rhodium(III)-catalyzed intramolecular hydroarylation, amidoarylation, and Heck-type reaction: Three distinct pathways determined by an amide directing group. Angew. Chem. Int. Ed. 2013, 52, 14181-14185. [CrossRef] [PubMed]

92. Wang, Y.; Li, C.; Li, Y.; Yin, F.; Wang, X.-S. Rhodium-Catalyzed C-H Olefination of Aryl Weinreb Amides. Adv. Synth. Catal. 2013, 355, 1724-1728. [CrossRef]

93. Wang, S.-M.; Li, C.; Leng, J.; Bukhari, S.N.A.; Qin, H.-L. Rhodium(iii)-catalyzed Oxidative Coupling of N-Methoxybenzamides and Ethenesulfonyl fluoride: A C-H Bond Activation Strategy for the Preparation of 2-Aryl ethenesulfonyl fluorides and Sulfonyl fluoride Substituted $\gamma$-Lactams. Org. Chem. Front. 2018, 5 , 1411-1415. [CrossRef]

94. Wang, C.-S.; Dixneuf, P.H.; Soulé, J.-F. Photoredox Catalysis for Building C-C Bonds from C(sp2)-H Bonds. Chem. Rev. 2018, 118, 7532-7585. [CrossRef] [PubMed]

95. Shaw, M.H.; Twilton, J.; MacMillan, D.W.C. Photoredox Catalysis in Organic Chemistry. J. Org. Chem. 2016, 81, 6898-6926. [CrossRef] [PubMed]

96. Romero, N.A.; Nicewicz, D.A. Organic Photoredox Catalysis. Chem. Rev. 2016, 116, 10075-10166. [CrossRef] [PubMed]

97. Lang, X.; Zhao, J.; Chen, X. Cooperative photoredox catalysis. Chem. Soc. Rev. 2016, 45, 3026-3038. [CrossRef] [PubMed]

98. Prier, C.K.; Rankic, D.A.; MacMillan, D.W.C. Visible Light Photoredox Catalysis with Transition Metal Complexes: Applications in Organic Synthesis. Chem. Rev. 2013, 113, 5322-5363. [CrossRef] [PubMed]

99. Fabry, D.C.; Rueping, M. Merging Visible Light Photoredox Catalysis with Metal Catalyzed C-H Activations: On the Role of Oxygen and Superoxide Ions as Oxidants. Acc. Chem. Res. 2016, 49, 1969-1979. [CrossRef] [PubMed]

100. Fabry, D.C.; Zoller, J.; Raja, S.; Rueping, M. Combining rhodium and photoredox catalysis for C-H functionalizations of arenes: Oxidative Heck reactions with visible light. Angew. Chem. Int. Ed. 2014, 53, 10228-10231. [CrossRef] [PubMed]

101. Fyfe, J.W.B.; Watson, A.J.B. Recent Developments in Organoboron Chemistry: Old Dogs, New Tricks. Chem 2017, 3, 31-55. [CrossRef]

102. Xu, L.; Zhang, S.; Li, P. Boron-selective reactions as powerful tools for modular synthesis of diverse complex molecules. Chem. Soc. Rev. 2015, 44, 8848-8858. [CrossRef] [PubMed] 
103. Lennox, A.J.J.; Lloyd-Jones, G.C. Selection of boron reagents for Suzuki-Miyaura coupling. Chem. Soc. Rev. 2014, 43, 412-443. [CrossRef] [PubMed]

104. Lehmann, J.W.; Blair, D.J.; Burke, M.D. Towards the generalized iterative synthesis of small molecules. Nat. Rev. Chem. 2018, 2, 0115. [CrossRef] [PubMed]

105. Li, J.; Grillo, A.S.; Burke, M.D. From Synthesis to Function via Iterative Assembly of N-Methyliminodiacetic Acid Boronate Building Blocks. Acc. Chem. Res. 2015, 48, 2297-2307. [CrossRef] [PubMed]

106. Li, J.; Ballmer, S.G.; Gillis, E.P.; Fujii, S.; Schmidt, M.J.; Palazzolo, A.M.E.; Lehmann, J.W.; Morehouse, G.F.; Burke, M.D. Synthesis of many different types of organic small molecules using one automated process. Science 2015, 347, 1221-1226. [CrossRef] [PubMed]

107. Woerly, E.M.; Roy, J.; Burke, M.D. Synthesis of most polyene natural product motifs using just 12 building blocks and one coupling reaction. Nat. Chem. 2014, 6, 484. [CrossRef] [PubMed]

108. Hartwig, J.F. Borylation and Silylation of C-H Bonds: A Platform for Diverse C-H Bond Functionalizations. Acc. Chem. Res. 2011, 45, 864-873. [CrossRef] [PubMed]

109. Mkhalid, I.A.; Barnard, J.H.; Marder, T.B.; Murphy, J.M.; Hartwig, J.F. C-H activation for the construction of C-B bonds. Chem. Rev. 2010, 110, 890-931. [CrossRef] [PubMed]

110. Smith, M.R.; Bisht, R.; Haldar, C.; Pandey, G.; Dannatt, J.E.; Ghaffari, B.; Maleczka, R.E.; Chattopadhyay, B. Achieving High Ortho Selectivity in Aniline $\mathrm{C}-\mathrm{H}$ Borylations by Modifying Boron Substituents. ACS Catal. 2018, 8, 6216-6223. [CrossRef] [PubMed]

111. Li, H.-L.; Kanai, M.; Kuninobu, Y. Iridium/Bipyridine-Catalyzed ortho-Selective C-H Borylation of Phenol and Aniline Derivatives. Org. Lett. 2017, 19, 5944-5947. [CrossRef] [PubMed]

112. Chattopadhyay, B.; Dannatt, J.E.; Andujar-De Sanctis, I.L.; Gore, K.A.; Maleczka, R.E.; Singleton, D.A.; Smith, M.R. Ir-Catalyzed ortho-Borylation of Phenols Directed by Substrate-Ligand Electrostatic Interactions: A Combined Experimental/in Silico Strategy for Optimizing Weak Interactions. J. Am. Chem. Soc. 2017, 139, 7864-7871. [CrossRef] [PubMed]

113. Hale, L.V.A.; Emmerson, D.G.; Ling, E.F.; Roering, A.J.; Ringgold, M.A.; Clark, T.B. An ortho-directed C-H borylation/Suzuki coupling sequence in the formation of biphenylbenzylic amines. Org. Chem. Front. 2015, 2, 661-664. [CrossRef]

114. Crawford, K.M.; Ramseyer, T.R.; Daley, C.J.A.; Clark, T.B. Phosphine-Directed C-H Borylation Reactions: Facile and Selective Access to Ambiphilic Phosphine Boronate Esters. Angew. Chem. 2014, 53, 7589-7593. [CrossRef] [PubMed]

115. Kawamorita, S.; Ohmiya, H.; Hara, K.; Fukuoka, A.; Sawamura, M. Directed Ortho Borylation of Functionalized Arenes Catalyzed by a Silica-Supported Compact Phosphine-Iridium System. J. Am. Chem. Soc. 2009, 131, 5058-5059. [CrossRef] [PubMed]

116. Hoque, M.E.; Bisht, R.; Haldar, C.; Chattopadhyay, B. Noncovalent Interactions in Ir-Catalyzed C-H Activation: L-Shaped Ligand for Para-Selective Borylation of Aromatic Esters. J. Am. Chem. Soc. 2017, 139, 7745-7748. [CrossRef] [PubMed]

117. Tajuddin, H.; Harrisson, P.; Bitterlich, B.; Collings, J.C.; Sim, N.; Batsanov, A.S.; Cheung, M.S.; Kawamorita, S.; Maxwell, A.C.; Shukla, L.; et al. Iridium-catalyzed C-H borylation of quinolines and unsymmetrical 1,2-disubstituted benzenes: Insights into steric and electronic effects on selectivity. Chem. Sci. 2012, 3, 3505-3515. [CrossRef]

118. Larsen, M.A.; Hartwig, J.F. Iridium-Catalyzed C-H Borylation of Heteroarenes: Scope, Regioselectivity, Application to Late-Stage Functionalization, and Mechanism. J. Am. Chem. Soc. 2014, 136, 4287-4299. [CrossRef] [PubMed]

119. Hartwig, J.F. Regioselectivity of the borylation of alkanes and arenes. Chem. Soc. Rev. 2011, 40, $1992-2002$. [CrossRef] [PubMed]

120. Ghaffari, B.; Preshlock, S.M.; Plattner, D.L.; Staples, R.J.; Maligres, P.E.; Krska, S.W.; Maleczka, R.E.; Smith, M.R. Silyl Phosphorus and Nitrogen Donor Chelates for Homogeneous Ortho Borylation Catalysis. J. Am. Chem. Soc. 2014, 136, 14345-14348. [CrossRef] [PubMed]

121. Newton, C.G.; Wang, S.-G.; Oliveira, C.C.; Cramer, N. Catalytic Enantioselective Transformations Involving C-H Bond Cleavage by Transition-Metal Complexes. Chem. Rev. 2017, 117, 8908-8976. [CrossRef] [PubMed]

122. Shirai, T.; Yamamoto, Y. Cationic Iridium/S-Me-BIPAM-Catalyzed Direct Asymmetric Intermolecular Hydroarylation of Bicycloalkenes. Angew. Chem. Int. Ed. 2015, 54, 9894-9897. [CrossRef] [PubMed] 
123. Erbing, E. Development of New Efficient Iridium-Catalyzed Methods for the Construction of Carbon-Heteroatom Bonds. Ph.D. Thesis, Stockholm University, Stockholm, Sweden, 2018.

124. Collins, K.D.; Glorius, F. A robustness screen for the rapid assessment of chemical reactions. Nat. Chem. 2013, 5, 597-601. [CrossRef] [PubMed]

125. Gensch, T.; Teders, M.; Glorius, F. Approach to Comparing the Functional Group Tolerance of Reactions. J. Org. Chem. 2017, 82, 9154-9159. [CrossRef] [PubMed]

126. Erbing, E.; Sanz-Marco, A.; Vázquez-Romero, A.; Malmberg, J.; Johansson, M.J.; Gómez-Bengoa, E.; Martín-Matute, B. Base- and Additive-Free Ir-Catalyzed ortho-Iodination of Benzoic Acids: Scope and Mechanistic Investigations. ACS Catal. 2018, 8, 920-925. [CrossRef]

127. Egorova, K.S.; Ananikov, V.P. Which Metals are Green for Catalysis? Comparison of the Toxicities of Ni, Cu, Fe, Pd, Pt, Rh, and Au Salts. Angew. Chem. Int. Ed. 2016, 55, 12150-12162. [CrossRef] [PubMed]

128. Hayler, J.D.; Leahy, D.K.; Simmons, E.M. A Pharmaceutical Industry Perspective on Sustainable Metal Catalysis. Organometallics 2019, 38, 36-46. [CrossRef]

129. Sherwood, J. European Restrictions on 1,2-Dichloroethane: C-H Activation Research and Development Should Be Liberated and not Limited. Angew. Chem. Int. Ed. 2018, 57, 14286-14290. [CrossRef] [PubMed]

130. Clarke, C.J.; Tu, W.-C.; Levers, O.; Bröhl, A.; Hallett, J.P. Green and Sustainable Solvents in Chemical Processes. Chem. Rev. 2018, 118, 747-800. [CrossRef] [PubMed]

131. Wilson, K.L.; Murray, J.; Sneddon, H.F.; Wheelhouse, K.M.P.; Watson, A.J.B. Connecting the Dots: Method Development Using Sustainable Solvents. Chem 2017, 3, 365-368. [CrossRef]

132. Welton, T. Solvents and sustainable chemistry. Proc. R. Soc. A Math. Phys. Eng. Sci. 2015, 471. [CrossRef] [PubMed]

(C) 2019 by the authors. Licensee MDPI, Basel, Switzerland. This article is an open access article distributed under the terms and conditions of the Creative Commons Attribution (CC BY) license (http:/ / creativecommons.org/licenses/by/4.0/). 